\title{
Efeitos de encadeamento e diversificação industrial comercial e produtiva: uma análise da Indonésia, Malásia e Tailândia entre 1980 e 2010 *
}

\author{
Cristina Fróes de Borja Reis **
}

\begin{abstract}
Resumo
Este artigo analisa a relação entre efeitos de encadeamento e a diversificação industrial comercial e produtiva em economias em desenvolvimento inicialmente especializadas em recursos naturais. Tal tarefa é realizada teórica e empiricamente, examinando-se os casos da Indonésia, Malásia e Tailândia através de matrizes insumo-produto e investigando as instituições associadas ao processo. Conclui-se que os efeitos de encadeamento da especialização primária sobre a indústria de processamento ocorreram; contudo não a ponto de sustentar a sofisticação industrial e a superação da heterogeneidade estrutural, além de não ser a principal explicação para o forte ritmo de industrialização realizado por essas economias.
\end{abstract}

Palavras-chave: Efeitos de encadeamento; Estrutura produtiva; Inserção externa; Desenvolvimento econômico; SEANICs.

\section{Abstract \\ Linkage effects and trade and productive diversification: an analysis of Indonesia, Malaysia and Thailand between 1980 and 2010}

This article examines the relationship between linkage effects and trade and productive manufacturing diversification in developing economies that initially specialized in natural resources. This analysis is carried out both theoretically and empirically, by examining the cases of Indonesia, Malaysia and Thailand through input-output matrices and the investigation of the institutional framework. The article concludes that there were linkage effects from the specialization in primary products to resource-based industries. This did not however take place to the point of sustaining industrial sophistication and overcoming structural heterogeneity, besides not being the main explanation for the fast pace of industrialization achieved by these economies.

Keywords: Linkage effects; Productive structure; External insertion; Economic development; SEANICs.

JEL O13, O14, O25, O30, O53.

* Artigo recebido em 14 de maio de 2014 e aprovado em 8 de dezembro de 2015. Derivado de tese de doutorado da autora no Instituto de Economia da Universidade Federal do Rio de Janeiro (IE/UFRJ), que contou com bolsa integral de doutorado através das Cotas do Programa de Pós-Graduação do CNPq (Conselho Nacional de Desenvolvimento Científico e Tecnológico) entre 2008 e 2012, bolsa CAPES de doutoramento-sanduíche de 2010 a 2011, e apoio CAPES para apresentação de trabalho no Japão em 2013 através do Programa de Apoio à Participação em Eventos no Exterior. Agradeço em especial ao Professor Carlos Aguiar de Medeiros por sua orientação à pesquisa que originou esse artigo, e também aos colegas Carolina Baltar e Aleix Altimiras pelo apoio na análise de dados das matrizes insumo-produto.

${ }^{* *}$. Professora do Centro de Engenharia, Modelagem e Ciências Sociais Aplicadas da Universidade Federal do ABC (UFABC), Santo André, SP, Brasil. Email: cristina.reis@ ufabc.edu.br. 


\section{Introdução}

A temática da especialização produtiva e exportadora em bens primários voltou ao debate em economia após a escalada da demanda e de preços desde os anos noventa. Diversos países periféricos verificaram reprimarização da pauta de exportações e desindustrialização, inclusive o Brasil. Já na segunda década do século XXI, os preços de diversas commodities passaram a cair, evidenciando a vulnerabilidade que a reprimarização causou naquelas economias. A visão estruturalista desde os anos cinquenta alerta quanto à necessidade da diversificação industrial para alcançar trajetórias sustentadas de desenvolvimento econômico, através de mecanismos diversos, incluindo os efeitos de encadeamento. Mesmo considerando as mudanças políticas, econômicas e sociais desde o pós-guerra, especialmente a partir da consolidação nos anos oitenta do padrão financeiro internacional do dólar-flexível, permanecem as principais inquietudes das teorias estruturalistas da tradição cepalina associadas às desigualdades geradas pela divisão internacional do trabalho. A compreensão da dinâmica produtiva e comercial internacional através daquela abordagem pode ser aportada para a discussão contemporânea, considerando ao menos três atualizações fundamentais: Primeiro, quanto à transformação da divisão clássica entre o "centro" produtor de manufaturas e a "periferia" produtora de recursos naturais. De um lado, a internacionalização dos processos produtivos liderada por empresas multinacionais do "centro", e também as estratégias nacionais de industrialização em alguns casos da periferia, possibilitaram a consolidação dos últimos como exportadores de manufaturas; de outro, o avanço tecnológico e aumento de produtividade nos setores de recursos naturais também levaram os países do centro a firmarem-se com exportadores expressivos de alimentos e matérias-primas. Em segundo lugar, os efeitos de encadeamento dos recursos naturais e da indústria de transformação variam em cada contexto local, a depender principalmente da sofisticação tecnológica envolvida na produção, não existindo a rigor uma regra em que a da manufatura seja superior à do recurso natural. Finalmente, porque as teorias estruturalistas apontavam para a necessidade de um planejamento de Estado para apoiar a industrialização e contribuir para a superação da heterogeneidade estrutural, notadamente por meio de políticas industriais e do regime macroeconômico. Tal tarefa exigiria a ascensão de coalizões de poder e tecnocracias capacitadas, um processo complexo e muitas vezes interditado por pressões de interesses internos e externos, além das dificuldades técnicas e financeiras, entre outras.

A fim de contribuir especialmente para a discussão sobre as relações entre efeitos de encadeamento e a diversificação industrial de um ponto de vista estruturalista, neste artigo realiza-se uma revisão teórica e crítica da literatura, na seção 1 , e o estudo de casos de três dos poucos países que realizaram mudança estrutural e diversificaram sua matriz produtiva e comercial para produtos industriais 
no contexto da globalização produtiva e financeira a partir dos anos oitenta: a Indonésia, a Malásia e a Tailândia - conhecidos como SEANICs (South East Asian Newly Industrialized Countries). Assim, na seção 2 investigam-se os efeitos de encadeamento através de matrizes insumo-produto e na seção 3 discutem-se as instituições associadas ao processo, para enfim levantar conclusões também sobre o papel dos efeitos de encadeamento e da diversificação industrial para o desenvolvimento econômico dos SEANICs.

\section{Efeitos de encadeamento e a superação da heterogeneidade estrutural em teoria}

A possibilidade de industrialização e diversificação da estrutura produtiva e comercial em economias atrasadas especializadas em recursos naturais tem sido discutida desde o nascimento da Economia Política. O debate em geral se polariza entre os autores favoráveis à especialização produtiva de acordo com o modelo das vantagens comparativas relativas e àqueles que defendem a diversificação para atividades industriais mais intensivas em capital, tecnologia e conhecimento.

Do lado das vantagens comparativas, as abordagens clássica, neoclássica ${ }^{1} \mathrm{e}$ suas ramificações (incluindo a Nova Economia Institucional (NEI)) defendem a especialização por supor que a alocação de recursos através do livre mercado (laissez faire) levaria a um estado estacionário de equilíbrio eficiente. Neste estado, os ganhos do progresso tecnológico na atividade manufatureira em apenas uma parte dos países seriam distribuídos para os outros que se especializaram em produtos primários, que não teriam, portanto, necessidade de se industrializar (Ocampo, 2007). De outro lado, os teóricos protecionistas, a teoria do imperialismo, a economia do desenvolvimento e as diversas teorias cepalinas, em geral através de uma abordagem mais estruturalista ${ }^{2}$, defendiam a industrialização em países atrasados a fim de internalizar o motor do desenvolvimento econômico. Isso porque nessa visão a industrialização desempenha um papel central na criação de efeitos de encadeamento (linkages) intersetoriais, inovações e progresso técnico que ocasionariam um estímulo endógeno mais expressivo para o crescimento, alavancando a produtividade da economia. Portanto, posicionam-se contrariamente à teoria das vantagens comparativas, alegando que a especialização e o livrecomércio perpetuariam as desigualdades econômicas entre produtores e exportadores de manufaturas e de recursos naturais. Partilhando da visão

(1) Embora existam muitas escolas específicas dentro desse corpo teórico, as teorias neoclássicas comungam do mesmo núcleo analítico: o modelo walrasiano de equilíbrio geral competitivo (Dymski, 2010). Estudos neoclássicos aqui também incluem os que tentam encontrar desvios do conjunto da suposição walrasiana, mas que realmente não implicam uma ruptura com o modelo.

(2) A definição de método "estrutural", segundo Rodriguez (2009) aplica-se à análise que foca na estrutura econômica, considerando o perfil das atividades produtivas, sua formação e transformações - e, portanto, é necessariamente, concomitantemente, histórica. 
estruturalista, nessa seção percorrem-se seus principais pontos relacionados a efeitos de encadeamento e superação da heterogeneidade estrutural.

A noção de efeitos de encadeamento contemporaneamente pode ser estendida para quatro categorias (Cicantell; Smith, 2005): 1) produtiva para frente (forward linkage) relacionada à utilização de produtos de certo setor como insumos em outros setores; 2) produtiva para trás (backward linkage) relacionada à demanda por insumos; 3) fiscal - ou seja, geração de receitas para o governo; 4) de demanda final - através do efeito multiplicador keynesiano. Ao longo do processo de encadeamento emergem ou se aperfeiçoam as instituições, re-alimentando e contribuindo na formatação do processo de desenvolvimento. A origem do conceito de linkages ou efeitos de encadeamento é atribuída à staple theory (Senghass, 1985), uma formulação teórica iniciada nos anos trinta que investigou como economias primárias que pertenceram ao domínio inglês se industrializaram e lograram o desenvolvimento econômico ${ }^{3}$. A staple theory defende que em alguns países que possuíam vantagens comparativas em certos produtos do setor primário, com demanda crescente em mercados internacionais, a expansão de sua produção e exportação gerou aumento de investimentos e de empregos, o que por sua vez encadeou maior demanda para outros setores da economia. Esta dinâmica resultou em transformações na estrutura produtiva e nas instituições (o que era desejável e teria de ser promovido pelo Estado), levando a maiores taxas de crescimento do PIB total e per capita. Nos anos cinquenta, a "economia do desenvolvimento" através de Hirschman (1958) cunhou o conceito de efeitos de encadeamento, mas assumindo que estes se mostraram fracos nos setores exportadores de recursos naturais - não sendo capazes de conferir um impulso dinâmico significativo para o desenvolvimento da economia. Assim Hirschman posicionou-se a favor da industrialização liderada pelo Estado, a partir de setores estratégicos.

Outro autor da "economia do desenvolvimento", Lewis (1954), discutiu a possibilidade de transformação estrutural diferenciando as trajetórias econômicas de regiões periféricas de acordo com a escassez ou abundância de mão-de-obra (apesar de que muitas vezes a revisão dessa literatura enfatize as diferenças de desenvolvimento em países de clima temperado e tropical). Inicialmente, ambos os casos se caracterizam por uma economia dual, que aqui será chamada de heterogeneidade estrutural - conforme Furtado (1974) - onde uma parte pequena da força de trabalho é empregada no setor exportador de produtos primários mais moderno, e a outra parte é alocada no setor não-exportador atrasado. $\mathrm{O}$ setor atrasado possui uma produtividade marginal de trabalho muito baixa, de forma que sua remuneração também o seja, exogenamente determinada ao nível do salário de

(3) A teoria do Produto Principal, ou do produto primário, surgiu no Canadá e seu autor mais importante é Innis (1933), o qual apresenta o desenvolvimento daquele país como um exemplo positivo resultante da natureza e da forma de inserção no comércio internacional de suas staples (produtos agrícolas, peixes, minerais, couro). 
subsistência. Assim, todo o fluxo de renda da economia depende do setor moderno (e da função de produção condicionada pelo avanço tecnológico), ou melhor, da taxa de investimento no mesmo e de sua demanda por trabalho. A partir dessas duas últimas variáveis, define-se o produto bruto a ser distribuído entre as classes em forma de salários, aluguéis e lucro (Cardoso, 2012). Por sua vez, a taxa de investimento do setor primário depende, afinal, da taxa de lucro dos capitalistas e do crescimento da demanda mundial (Findlay; Lundahl, 2002). Destarte, nas economias em que há oferta ilimitada de trabalho, o que implica em baixa pressão sobre os salários, há uma tendência de baixos níveis de investimento por trabalhador e de crescimento da produtividade no setor exportador - gerando baixos efeitos multiplicadores de emprego e demanda para os demais setores da economia. De modo contrastante, nas regiões em que houve pressão salarial, o setor exportador tendeu a apresentar maiores salários e produtividade, gerando efeitos multiplicadores como na staple theory.

A análise de Prebisch [2000 (1949)], autor também da "economia do desenvolvimento", reafirma a fragilidade de modelos de desenvolvimento baseados na exportação de recursos naturais, pois exibem ganhos de produtividade menores do que nas economias que diversificam sua produção e exportações para manufaturas - o que implicaria uma tendência de deterioração dos termos de troca ao longo do tempo. ${ }^{4} \mathrm{O}$ diferencial de produtividade seria devido à oferta ilimitada de mão-deobra nas regiões agrárias - que não pressiona salários e não incentiva o progresso técnico -, à demanda mais inelástica dos produtos primários em relação aos manufaturados e aos oligopólios industriais. Portanto, para o autor a especialização comercial beneficiaria de forma relativamente simétrica apenas quando os parceiros comerciais detêm estrutura econômica parecida; ao contrário, o comércio entre nações desiguais aprofundaria a desigualdade (Macedo e Silva, 2008). Porém, exportar recursos naturais em nações atrasadas é importante pois se constitui uma fonte crucial de divisas para reduzir a restrição externa na balança de pagamentos, além de propiciar excedentes para o governo (através de tributação) e para os capitalistas nacionais ou internacionais que dominam esse setor. Caso as receitas advindas da taxação sejam revertidas em gasto público (corrente e de investimento, este último em infraestrutura e/ ou atividades empresariais), e/ ou os lucros sejam reinvestidos em produção industrial de maior valor adicionado, o setor exportador torna-se capaz de acelerar a mudança estrutural na economia e sustentar o processo de crescimento de longo prazo.

(4) A noção de "deterioração dos termos de troca" afirma que ao longo do tempo os ganhos de produtividade seriam substancialmente maiores na indústria ante a atividade primária, mas que tais ganhos não seriam repassados totalmente para os preços, como no segundo caso. Então, ao contrário do que sugeria a teoria das vantagens comparativas, haveria uma queda de preços relativos dos bens agrícolas ante os industriais, indicando um bloqueio na propagação do progresso técnico nas manufaturas e conduzindo à deterioração dos termos de trocas entre os dois grupos de países. 
Assim, os diferentes autores da staple theory e da "escola do desenvolvimento" sugerem que a superação da heterogeneidade estrutural e a diversificação industrial dependem principalmente das diferenças associadas à disponibilidade de trabalhadores e a produtividade do trabalho - como enfatiza também Furtado (1976) -, das características do mercado de commodities, dos efeitos de encadeamento do setor de exportação e da aplicação das rendas de exportação dos recursos naturais. Na visão estruturalista, a atuação do Estado firmase como uma via interessante para se operar mudanças significativas nos termos de comércio de uma região ou país para reverter a especialização primário-exportadora em direção da diversificação manufatureira. Por outro lado, considera-se que não somente os determinantes internos devem ser examinados para compreender as trajetórias econômicas dos países, mas também a economia política internacional. Afinal, a transformação do modelo exportador e a superação da heterogeneidade estrutural se mostra escassa no jogo de competição capitalista internacional, haja vista o pequeno número de países desenvolvidos no mundo. É por isso que os recentes trabalhos matério-espaciais em sociologia e geografia ${ }^{5}$, herdeiros da staple theory, analisam os padrões de especialização dos países considerando a globalização financeira e produtiva e usando as características espaciais e materiais como parâmetros para entender as tecnologias (e a produção em geral), os mercados (e as instituições em geral) e a interação de forças (geo)políticas ${ }^{6}$. Entre as características materiais e espaciais que moldam a especialização, essa abordagem destaca os custos irrecuperáveis ou afundados, que influenciam o comportamento do investimento das empresas, o desempenho de indústrias de primárias de várias maneiras, incluindo seus efeitos de encadeamento e a inércia do padrão de especialização produtiva.

Por fim, é preciso salientar que a teoria dos efeitos de encadeamento é alvo de quatro tipos de críticas principais, tanto enquanto construção teórica, quanto prática - empenhada como base para o planejamento do desenvolvimento econômico. Em primeiro lugar, como Bunker (1989) argumenta, indústrias encadeadas tendem a aglomerar-se geograficamente em volta do setor relacionado, gerando discrepâncias espaciais em um país. Fracos efeitos de encadeamento emergem entre regiões em face de altos custos de transporte, de infraestrutura e

(5) A moderna teoria "matério-espacial" examina os aspectos microeconômicos da produção sob uma perspectiva neo-marxista do sistema capitalista internacional.

(6) As estratégias de poder para acessar matérias-primas configuraram a vida social, política e econômica das regiões subdesenvolvidas incorporadas ao seu raio de dominação, muitas vezes através de exploração pesada e extravio de sua riqueza natural. As matérias-primas formatam a organização e operação de demanda da economia devido à sua relativa escassez, localização e concentração geográfica, tecnologia de extração, produção e comercialização. A coordenação de respostas de empresas e Estados àquela competição entre empresas e interestatal, dadas as condições matério-espaciais, depende da capacidade tecnológica e de investimento, portanto das instituições financeiras, dos sistemas de aprendizado e conhecimento e das forças militares também. (Bunker; Cicantell, 2005, p. 34). 
outros custos associados à dispersão geográfica das indústrias - principalmente em países grandes. Em segundo lugar, a teoria de Hirschman assume a existência de um Estado política e economicamente forte e a racionalidade técnica de planejamento de desenvolvimento para executar esses planos, baseada na existência de um grupo de tecnocratas qualificados - o que não necessariamente se confirma na prática, denotando certa ingenuidade no aspecto normativo (Cicantell; Smith, 2005). A terceira crítica é quanto à produtividade e à intensidade dos efeitos de encadeamento da produção primária ${ }^{7}$. Há casos em que os efeitos são fortes e a produtividade é alta, ao invés de fracos e baixa - como insinua a maior parte da literatura, tanto no passado, quanto no presente. A história comprova que há países que se desenvolveram com base em recursos naturais, onde inovações tecnológicas geradas nestes setores promoveram aumento de produtividade, efeitos de encadeamento e transbordamento positivos para o resto da economia. Por exemplo, nos EUA a abundância de recursos per se foi mais um resultado das capacidades tecnológicas do que de dotações iniciais (Wright; Czelusta, 2003). E no presente, indústrias extrativas e também o agronegócio em boa medida se caracterizam por alta produtividade - como no caso brasileiro. Ou seja, a "abundância", e a subsequente "especialização", são fenômenos que podem ter um significativo componente causal endógeno.

A crítica derradeira é que a análise dos efeitos de encadeamento privilegia os efeitos do setor exportador pelo lado da oferta (ainda que incluam o efeito fiscal e de demanda final), quando os efeitos estruturais sobre a demanda também são muito relevantes. Como Furtado $(1957,1974)$ demonstrou, o que pode diferenciar o setor de exportações de economias inicialmente especializadas em recursos naturais a ponto de superar a heterogeneidade estrutural seria o aumento notável na produtividade, propiciando elevados salários no setor exportador. Na sua visão, em face da alta produtividade agrícola (com aprimoramento tecnológico), os preços relativos dos alimentos não se elevam tanto, portanto o poder de compra dos salários cresce relativamente. A maior renda da agricultura favorece a expansão do mercado interno, com consequente elevação dos salários urbanos, retroalimentando o processo de modernização agrícola (Medeiros, 2008). Como resultado, a heterogeneidade estrutural diminui e até pode ser superada ${ }^{8}$. Este foi o caso de Austrália, Canadá, Nova Zelândia e Argentina, em contraste com Brasil e África do Sul, por exemplo (Senghaas, 1985). Aumentos na produtividade per se não necessariamente são originados por técnicas mais intensivas em capital. Podem ser

(7) Rocha (2010), em seu estudo sobre os efeitos de encadeamento do setor exportador entre 1970 e 2000 , no mundo, conclui que são fortes porque (i) o setor de exportação de RN tem maior produtividade do que o setor voltado para o mercado interno; (ii) as exportações de RN proporcionam efeitos de transbordamento positivos para o setor doméstico; e (iii) sua produtividade e encadeamento para a economia são pelo menos tão elevados quanto aqueles fornecidos pelo setor de exportação de manufaturas.

(8) O processo contrário teria sido o entrave principal da economia venezuelana (Medeiros, 2008). 
simplesmente um resultado do uso extensivo de fatores. Quando desacompanhados da substancial elevação dos salários e da modernização agrícola, a superação da heterogeneidade estrutural ou da armadilha da pobreza tendem a não se consagrar. Mais do que elevar a produtividade, a modernização agrícola é um processo complexo que transforma as estruturas sociais no campo, que estão relacionadas a contextos geográficos, institucionais e demográficos específicos - integrando a economia e propiciando a redução das desigualdades inter-setoriais.

\section{Efeitos de encadeamento e a diversificação industrial na Indonésia, Malásia e Tailândia}

A Indonésia, a Malásia e a Tailândia pertencem ao sudeste asiático, são nações populosas e possuem territórios de porte médio a grande. ${ }^{9}$ Antes da II Guerra o Reino Unido dominava a península Malai e o norte da Ilha de Bornéu - incluindo Singapura e Malásia. A Holanda detinha a Indonésia, e o Sião, atual Tailândia, sempre foi independente. Entre 1941 e 1942 os japoneses invadiram os dois primeiros países com o apoio da Tailândia. Após a expulsão dos japoneses, os EUA intervieram e estabeleceram uma aliança bilateral com os tailandeses, apoiando a continuidade da ditadura militar ali existente desde 1932 até 1988. A Indonésia tornou-se independente nos anos cinquenta e vivenciou ditaduras militares até 1997. E a atual Malásia se formou em 1965, após a separação de Singapura. Assim, do ponto de vista político, os SEANICs no início dos anos oitenta eram Estados militares, altamente centralizados e nacionalistas, ainda que sob influência significativa dos EUA e do Japão. A escassez de grupos privados fortes e coesos contribuiu para a formação de Estados Desenvolvimentistas ${ }^{10}$, que procuraram coordenar e induzir investimentos privados através dos planos de desenvolvimento, apoiados em medidas de atração de investimentos diretos, políticas de crédito, subsídios, compras nos setores estratégicos etc. Na Indonésia, o Repelita I (Primeiro Plano quinquenal de Desenvolvimento) ${ }^{11}$ em 1969; na Malásia, a Nova Política

(9) A Malásia é o $67^{\circ}$ com maior território do mundo, Tailândia o $51^{\circ}$ e Indonésia o $15^{\circ}$. Em termos de população, a Malásia em 2011 ocupava o $43^{\circ}$ lugar no ranking internacional - com 29 milhões de habitantes, a Tailândia o $20^{\circ}$ - com 67 milhões de habitantes, e a Indonésia o $4^{\circ}$ - com 250 milhões (constituindo também a maior nação de religião muçulmana), de acordo com CIA (2012).

(10) O desenvolvimentismo emergiu como uma ideologia e uma estratégia de acumulação predominantemente coordenada pelos Estados Nacionais, de cujas diferentes trajetórias e vias de implementação dependeram da base de RN do país, da distribuição de renda, do tamanho da economia e de sua inserção geopolítica (Medeiros, 2012). Só que a constatação de Estados desenvolvimentistas, ou ainda, de políticas industriais nos SEANICs, não são um consenso. Por exemplo, BM (1993) atribui o milagre econômico a instituições "prómercado", negando existência de política industrial na Indonésia e na Malásia, e negando que a da Tailândia foi a causa do processo (Jomo, 1999).

(11) No Repelita 1 (1969/1974), o Estado estimulou substituição de importações em indústrias intensivas em trabalho e recursos naturais, de larga escala, estimulando principalmente os negócios dos indo-chineses. O Repelitta 2 (1974-1979) seguiu a mesma linha do primeiro plano, e ambos os planos estimulavam também exportações para gerar entrada de divisas (Rasiah, 2003). 
Econômica ${ }^{12}$ (também primeiro plano) em 1970; em 1972, o $3^{\circ}$ Plano Quinquenal da Tailândia (University of Cambridge, 1992, p. 474).

Do ponto de vista econômico, o compromisso crucial dos estados que então se fortaleciam era encontrar soluções para as complexas tarefas de industrialização tardia, particularmente a dependência ao capital externo. Os regimes econômicos após os anos oitenta tiveram um viés híbrido, nacionalistas em alguns pontos e internacionalizados em outros, com estratégias voltadas à promoção da grande empresa, atentando-se para os processos de globalização produtiva e para a industrialização derivada dos segmentos primários aproveitando efeitos de deslocamento, ainda que com temporalidades diferentes (antecipadamente na Malásia e tardiamente na Indonésia). Em todos, houve uma nítida preponderância dos imigrantes chineses nos negócios, que tiveram papel importante nos processos de diversificação produtiva desses países (University of Cambridge, 1992; Jomo, 1999). E do ponto de vista geopolítico, os estados desenvolvimentistas emergiram também como resposta aos conflitos na região ${ }^{13}$, consolidando governos militares minimamente desenvolvidos economicamente e centralizados politicamente para não serem engolfados pelos oponentes dos EUA na Guerra Fria. A própria ASEAN (Associação das Nações do Sudeste Asiático), de 1967, foi formada com base em um princípio defensivo, amplamente apoiada pelos EUA. Os norte-americanos eram os principais interventores na região ${ }^{14}$. Como a ASEAN ainda não tinha capacidade política e econômica para se fortalecer enquanto bloco, os seus integrantes estabeleceram acordos bilaterais com os EUA para implantação de bases militares (em geral, do tipo concessão) - principalmente a Tailândia. Após o final da Guerra do Vietnã, em 1975, e aproveitando-se do enfraquecimento do poder americano, o Japão fomentou o regionalismo asiático, aprofundando a sua inserção na ASEAN para ter acesso a matérias-primas em condições mais favoráveis, para expandir o mercado de sua indústria de alto valor agregado e para a internacionalização de suas empresas em um contexto de custos crescentes domésticos e do boom dos preços do petróleo. Os investimentos externos e a realocação dos processos produtivos das empresas multinacionais japonesas, dos NICs de primeira geração e americanas -

(12) A NEP (New Economic Policy ou DEB - Dasar Ekonomi Baru) foi um programa econômico e social transcorrido entre 1970 e 1990 que teve dois principais objetivos: erradicar a pobreza e reestruturar a economia para eliminar as correlações entre raça e atividade econômica.

(13) Durante a Guerra Fria, o sudeste asiático foi uma das regiões mais disputadas entre as grandes potências no mundo - sendo palco de uma das principais guerras da segunda metade do século, a do Vietnã. EUA e Inglaterra mantiveram laços estreitos com seus ex-domínios e protetorados também para a contenção dos movimentos comunistas (sob a influência chinesa ou russa) (University of Cambridge, 1992, p. 459).

(14) O que foi substancializado desde a SEATO (South-East Asia Treaty Organization) através do Tratado de Defesa Coletiva do Sudeste Asiático, de 1954, incluindo Austrália, França, Nova Zelândia, Paquistão, Filipinas, Tailândia, Reino Unido e EUA. 
especialmente após o Acordo Plaza ${ }^{15}$ - consolidaram a estratégia de industrialização orientada para exportações dos SEANICs e possibilitaram até mesmo o fortalecimento da ASEAN (que se tornou o bloco regional mais forte do Terceiro Mundo, ainda que sob "custódia" das grandes potências).

Indonésia, Malásia e Tailândia registraram altas taxas de crescimento entre 1980 e 2010, de 5,4\% a 6,0\% ao ano em média de acordo com WDI (2011). O PIB per capita evoluiu a um ritmo mais lento, entre $3,5 \%$ e $4,3 \%$, porque a população aumentou bastante no período (de 7,3\% a 13,1\%). Na mesma época, a indústria dos SEANICs como parcela do Valor Adicionado Total (VAT) cresceu mais de dez pontos percentuais, tomando espaço do setor primário e confirmando a indústria como principal setor, chegando a $27 \%$ na Indonésia, 30\% Malásia, e $40 \%$ na Tailândia, conforme se depreende da Tabela 1. Em particular, a indústria de transformação passou de $17,2 \%$ do VAT entre 1980 e 1984 para $28,1 \%$ entre 2005 e 2009 na Indonésia, de 15\% para 28\% na Malásia e 22\% para 34\% na Tailândia. Porém há significativo contraste entre a evolução das estruturas do VAT e do emprego. Ao final do período, enquanto agricultura, caça, florestais e pesca corresponderam de $8 \%$ a $13 \%$ do valor adicionado nos três países, em termos de emprego chegaram a corresponder a cerca de $40 \%$ do total na Tailândia e Indonésia - indicando que a dualidade estrutural permaneceu. Somente na Malásia o emprego desse setor se reduziu bastante para 14\% em 2006-10 (exibindo distribuição similar à dos países desenvolvidos). Mineração e extração, cuja participação no VAT caiu pela metade em 30 anos na Indonésia e na Malásia (não era expressiva na Tailândia), de $24 \%$ para $12 \%$, em termos de emprego não corresponde a nem $1 \%$. A parcela da indústria da transformação no emprego dos SEANICs corresponde a quase a metade da sua parcela no VAT. Em serviços houve uma correspondência mais equilibrada entre VAT e emprego na Tailândia e na Indonésia, com parcela média na casa dos $40 \%$. Porém na Malásia serviços correspondem a 50\% do VAT e $65 \%$ do emprego. Cabe ressaltar, ainda, que a participação da indústria de transformação no VAT foi mais elevada na Indonésia e na Malásia entre 2000 e 2004, tendo perdido parcela para o setor de serviços na Malásia e para o setor extrativo e primário na Indonésia na segunda metade da década dos 2000 por conta da elevação dos preços das commodities, o que já aponta algumas diferenças importantes no padrão de diversificação industrial desses países.

Nas exportações, ainda na Tabela 1, houve nos três países uma expressiva recomposição da pauta a favor das manufaturas - que de 1980-1984 a 2005-2009 passaram de uma parcela de 4,8\%, 22,8\% e 29,0\% na Indonésia, Malásia e Tailândia,

(15) O Acordo de Plaza foi realizado no Hotel Plaza em Nova Iorque, em que Alemanha, EUA, França, Japão e Reino Unido concordaram uma estratégia combinada de desvalorizar o dólar americano em relação às moedas dos outros países. Como consequência, as moedas dos países avançados, Coreia e Japão se apreciaram (Reis, 2013) 
respectivamente, para 42,1\%, 71,3\% e 75,8\% segundo OMC (2012). Na Indonésia, as manufaturas substituíram os combustíveis nas exportações, que retraíram de $75,4 \%$ para $28 \%$ no mesmo período. As manufaturas exportadas pela Indonésia constituíam-se principalmente de químicos, equipamentos de escritório e telecomunicações e vestuário. Na Malásia, as manufaturas aumentaram em substituição aos outros produtos. As reduções mais significativas foram de matériasprimas agrícolas (de $24 \%$ para $2 \%$ ) e de combustíveis (de $29 \%$ para $15 \%$ ). Na Tailândia, as manufaturas cresceram substituindo a participação do setor de alimentos, que reduziram de $43 \%$ para 13\%. Assim, na Tailândia e na Malásia, as exportações da indústria de transformação alcançaram cerca de três quartos do total, mais concentradas em equipamentos de escritório e telecomunicações, químicos e produtos automotivos - no caso da Tailândia. Como consequência, em termos de intensidade tecnológica (Tabela 2), o segmento de alta tecnologia representava ao final do período estudado (média 2005/2009) 45\% do total da pauta da Malásia, $31,5 \%$ da Tailândia e apenas $11,2 \%$ da Indonésia. Média intensidade tecnológica representava $24 \%$ do total das exportações da Tailândia e $10,7 \%$ da Malásia - o que significa que esses dois países têm mais da metade do seu conteúdo exportado nos segmentos mais intensos em tecnologia. Entretanto, ambos ainda têm uma participação significativa dos produtos primários e intensivos em energia na pauta, mas não tanto quanto a Indonésia, onde representam quase $60 \%$ das exportações. Cabe destacar, ainda, que nos três países os produtos intensivos em mão-de-obra, que tiveram participação expressiva sobretudo nos anos noventa, perderam importância na pauta.

Aprofundando a análise sobre a diversificação industrial, comparando a configuração atual do VTI (Valor da Transformação Industrial) e do emprego industrial, notam-se diferenças consideráveis nos perfis da indústria da transformação dos SEANICs (Tabela 4). A Indonésia possui um perfil mais concentrado em setores tradicionais de países pouco industrializados: alimentos e bebidas, produtos de tabaco, têxteis e vestuário respondem por $45 \%$ do emprego e $35 \%$ do VTI ao final do período estudado. No entanto, há que destacar a importância da indústria química no VTI $(13,9 \%)$ e veículos automotores $(9,5 \%)$, sem paralelo no emprego (4,9\% e 2,0\%, respectivamente). Na Malásia, as indústrias principais são de telecomunicações (15,8\% do VTI e 13,8\% do emprego industrial), ressaltando-se que houve uma forte queda na importância do setor, pois em 2000 suas parcelas no emprego industrial e no VTI eram superiores a 20\%. Em substituição, ganharam importância no VTI os setores de petróleo refinado e coque (17,6\%), equipamentos de escritório $(10,7 \%)$ e químicos $(11,8 \%)$ - indústrias menos intensivas em mão-de-obra, o que significa que suas contribuições no emprego são menores do que no VTI. Na Tailândia, primeiramente vem alimentos e bebidas (16,5\% do VTI e 17,9\% do emprego industrial), equipamentos de telecomunicações $(14,7 \%$ e $7,6 \%)$ e veículos automotores $(12,9 \%$ e $5,1 \%)$. 
Tabela 1A

Composição do Valor Adicionado (\$ constante 2005, em \%), do Emprego Nacional (\% do Emprego Total) e das Exportações de bens (\$ constante, em \%) dos SEANICs, médias quinquenais de 1980 a 2009, SEANICs (\% total exportado)

\begin{tabular}{|c|c|c|c|c|c|c|}
\hline \multirow[b]{2}{*}{ Quinquênio } & \multicolumn{6}{|c|}{ Indonésia } \\
\hline & $80-84$ & $85-89$ & $90-94$ & $95-99$ & $00-04$ & 05-09 \\
\hline Primário & 43,8 & 36,5 & 30,8 & 28,5 & 28,6 & 25,3 \\
\hline Agricultura, caça, pesca e floresta & 19,9 & 18,7 & 15,2 & 13,5 & 13,8 & 13,0 \\
\hline Mineração e Extração & 23,8 & 17,8 & 15,6 & 15,1 & 14,9 & 12,2 \\
\hline Indústria & 17,5 & 22,6 & 26,2 & 28,2 & 29,1 & 26,8 \\
\hline Indústria da transformação & 17,2 & 22,2 & 25,7 & 27,5 & 28,1 & 25,7 \\
\hline Serviços & 38,8 & 40,8 & 43,0 & 43,3 & 42,3 & 48,0 \\
\hline Comércio, restaurante e hotéis & 12,9 & 13,5 & 14,7 & 14,9 & 14,9 & 16,4 \\
\hline Transp, armaz. e comunicações & 4,3 & 4,3 & 4,3 & 4,5 & 5,3 & 7,7 \\
\hline Financeiro, imóveis, seguros & 2,7 & 4,5 & 6,0 & 6,4 & 5,5 & 6,0 \\
\hline Primário & 55,9 & 53,1 & 53,8 & 44,8 & 44,4 & 41,8 \\
\hline Agricultura & 55,1 & 52,2 & 52,9 & 43,8 & 43,5 & 40,8 \\
\hline Mineração & 0,8 & 0,8 & 0,9 & 1,0 & 0,9 & 0,9 \\
\hline Indústria & 9,3 & 11,1 & 11,6 & 12,9 & 12,8 & 12,2 \\
\hline Indústria da transformação & 9,2 & 10,9 & 11,4 & 12,7 & 12,6 & 12,1 \\
\hline Serviços & 34,8 & 35,9 & 34,6 & 42,3 & 42,8 & 46,0 \\
\hline Comércio, restaurante e hotéis & 13,6 & 14,4 & 13,7 & 17,1 & 18,5 & 20,8 \\
\hline Transp, armaz. e comunicações & 3,1 & 3,4 & 3,5 & 4,6 & 5,3 & 5,7 \\
\hline Financeiro, imóveis, seguros & 0,6 & 0,7 & 0,8 & 1,0 & 1,8 & 1,7 \\
\hline Primário & 14,5 & 20,9 & 16,1 & 17,6 & 14,6 & 20,7 \\
\hline Alimentos & $6,2 \%$ & $12,3 \%$ & $11,3 \%$ & $12,2 \%$ & $10,4 \%$ & $14,9 \%$ \\
\hline Combust. e minérios & 80,7 & 56,1 & 37,2 & 30,7 & 32,3 & 37,3 \\
\hline Manufaturas & 4,8 & 23,0 & 46,7 & 51,7 & 53,1 & 42,1 \\
\hline Aço e ferro & ND & ND & $0,9 \%$ & $0,9 \%$ & $0,8 \%$ & $1,4 \%$ \\
\hline Químicos & ND & ND & $2,5 \%$ & $4,2 \%$ & $5,2 \%$ & $5,3 \%$ \\
\hline $\begin{array}{l}\text { Máquinas e equipamentos } \\
\text { transporte }\end{array}$ & ND & ND & $4,7 \%$ & $10,2 \%$ & $16,7 \%$ & $13,8 \%$ \\
\hline $\begin{array}{l}\text { Equipamentos de escritório e } \\
\text { telecom }\end{array}$ & $0,4 \%$ & $0,2 \%$ & $2,6 \%$ & $5,9 \%$ & $10,2 \%$ & $5,5 \%$ \\
\hline Produtos automotivos & ND & ND & $0,1 \%$ & $0,4 \%$ & $0,9 \%$ & $1,8 \%$ \\
\hline Têxteis & $0,4 \%$ & $2,8 \%$ & $6,7 \%$ & $5,7 \%$ & $5,0 \%$ & $3,2 \%$ \\
\hline Vestuário & $0,7 \%$ & $3,7 \%$ & $8,4 \%$ & $7,1 \%$ & $7,0 \%$ & $5,2 \%$ \\
\hline
\end{tabular}


Tabela 1B

\begin{tabular}{|c|c|c|c|c|c|c|}
\hline \multirow[b]{2}{*}{ Quinquênio } & \multicolumn{6}{|c|}{ Malásia } \\
\hline & $80-84$ & $85-89$ & $90-94$ & $95-99$ & $00-04$ & $05-09$ \\
\hline Primário & 44,8 & 43,7 & 32,1 & 26,3 & 23,7 & 20,5 \\
\hline Agricultura, caça, pesca e floresta & 20,7 & 19,2 & 14,7 & 10,1 & 9,0 & 8,3 \\
\hline Mineração e Extração & 24,1 & 24,4 & 17,4 & 16,2 & 14,7 & 12,2 \\
\hline Indústria & 16,9 & 19,5 & 25,8 & 28,8 & 30,6 & 30,1 \\
\hline Indústria da transformação & 15,6 & 17,8 & 23,9 & 26,5 & 28,0 & 27,5 \\
\hline Serviços & 38,3 & 36,8 & 42,1 & 45,0 & 45,7 & 49,3 \\
\hline Comércio, restaurante e hotéis & 12,0 & 11,0 & 14,2 & 14,9 & 14,2 & 15,6 \\
\hline Transp, armaz. e comunicações & 4,5 & 4,9 & 5,4 & 6,1 & 6,7 & 7,2 \\
\hline Financeiro, imóveis, seguros & 5,5 & 6,1 & 8,2 & 10,1 & 12,0 & 13,6 \\
\hline Primário & 32,6 & 29,9 & 22,1 & 16,9 & 14,7 & 14,0 \\
\hline Agricultura & 31,7 & 29,3 & 21,7 & 16,5 & 14,4 & 13,6 \\
\hline Mineração & 0,9 & 0,6 & 0,5 & 0,4 & 0,3 & 0,4 \\
\hline Indústria & 14,7 & 15,4 & 21,3 & 25,4 & 24,2 & 20,8 \\
\hline Indústria da transformação & 13,7 & 14,3 & 20,2 & 24,1 & 23,1 & 19,7 \\
\hline Serviços & 52,7 & 54,8 & 56,5 & 57,7 & 61,0 & 65,2 \\
\hline Comércio, restaurante e hotéis & 17,9 & 20,0 & 20,7 & 19,8 & 21,3 & 22,5 \\
\hline Transp, armaz. e comunicações & 4,5 & 4,8 & 5,2 & 5,9 & 5,8 & 6,1 \\
\hline Financeiro, imóveis, seguros & 4,2 & 4,7 & 5,8 & 6,7 & 7,0 & 8,3 \\
\hline Primário & 42,3 & 35,7 & 20,1 & 13,4 & 9,7 & 11,9 \\
\hline Alimentos & $16,7 \%$ & $15,5 \%$ & $10,3 \%$ & $9,0 \%$ & $7,3 \%$ & $9,5 \%$ \\
\hline Combust. e minérios & 34,9 & 23,8 & 13,5 & 8,6 & 11,2 & 16,8 \\
\hline Manufaturas & 22,8 & 40,5 & 66,4 & 78,1 & 79,1 & 71,3 \\
\hline Aço e ferro & $0,1 \%$ & ND & $0,8 \%$ & $0,7 \%$ & $1,0 \%$ & $1,6 \%$ \\
\hline Químicos & $0,6 \%$ & ND & $2,2 \%$ & $3,3 \%$ & $4,8 \%$ & $5,9 \%$ \\
\hline $\begin{array}{l}\text { Máquinas e equipamentos } \\
\text { transporte }\end{array}$ & $11,1 \%$ & ND & $46,2 \%$ & $58,3 \%$ & $59,4 \%$ & $49,4 \%$ \\
\hline $\begin{array}{l}\text { Equipamentos de escritório e } \\
\text { telecom }\end{array}$ & $12,2 \%$ & $21,2 \%$ & $35,6 \%$ & $47,6 \%$ & $49,7 \%$ & $39,1 \%$ \\
\hline Produtos automotivos & $0,1 \%$ & ND & $0,4 \%$ & $0,4 \%$ & $0,4 \%$ & $0,6 \%$ \\
\hline Têxteis & $1,1 \%$ & $1,2 \%$ & $1,4 \%$ & $1,5 \%$ & $1,1 \%$ & $0,9 \%$ \\
\hline Vestuário & $1,5 \%$ & $3,5 \%$ & $4,2 \%$ & $3,0 \%$ & $2,1 \%$ & $1,9 \%$ \\
\hline
\end{tabular}


Tabela 1C

\begin{tabular}{|c|c|c|c|c|c|c|}
\hline \multirow[b]{2}{*}{ Quinquênio } & \multicolumn{6}{|c|}{ Tailândia } \\
\hline & $80-84$ & $85-89$ & $90-94$ & 95-99 & 00-04 & 05-09 \\
\hline Primário & 21,1 & 19,3 & 14,8 & 13,8 & 15,0 & 13,8 \\
\hline Agricultura, caça, pesca e floresta & 19,6 & 16,9 & 12,5 & 11,2 & 11,9 & 10,6 \\
\hline Mineração e Extração & 1,5 & 2,4 & 2,3 & 2,6 & 3,1 & 3,2 \\
\hline Indústria & 23,7 & 25,4 & 29,9 & 33,3 & 37,5 & 39,7 \\
\hline Indústria da transformação & 21,9 & 23,3 & 27,6 & 30,6 & 34,3 & 36,5 \\
\hline Serviços & 55,2 & 55,3 & 55,4 & 52,9 & 47,5 & 46,5 \\
\hline Comércio, restaurante e hotéis & 25,8 & 26,4 & 24,7 & 22,9 & 21,2 & 20,3 \\
\hline Transp, armaz. e comunicações & 5,0 & 5,4 & 5,7 & 6,6 & 7,5 & 7,6 \\
\hline Financeiro, imóveis, seguros & 1,6 & 2,6 & 6,0 & 5,6 & 2,5 & 3,0 \\
\hline Primário & 67,7 & 66,3 & 59,2 & 50,3 & 45,6 & 41,7 \\
\hline Agricultura & 67,4 & 66,1 & 59,0 & 50,1 & 45,5 & 41,6 \\
\hline Mineração & 0,3 & 0,2 & 0,2 & 0,1 & 0,1 & 0,1 \\
\hline Indústria & 8,3 & 8,5 & 11,2 & 12,9 & 14,7 & 14,8 \\
\hline Indústria da transformação & 7,9 & 8,2 & 10,8 & 12,4 & 14,4 & 14,5 \\
\hline Serviços & 24,1 & 25,1 & 29,7 & 36,8 & 39,6 & 43,5 \\
\hline Comércio, restaurante e hotéis & 11,3 & 12,4 & 13,5 & 17,1 & 20,0 & 21,4 \\
\hline Transp, armaz. e comunicações & 2,1 & 2,2 & 2,6 & 3,0 & 2,9 & 2,9 \\
\hline Financeiro, imóveis, seguros & 1,0 & 1,0 & 1,5 & 2,2 & 2,4 & 2,9 \\
\hline Primário & 62,7 & 45,6 & 29,1 & 23,3 & 18,7 & 17,5 \\
\hline Alimentos & $53,2 \%$ & $37,8 \%$ & $24,5 \%$ & $18,9 \%$ & $14,6 \%$ & $12,8 \%$ \\
\hline Combust. e minérios & 8,2 & 2,8 & 1,6 & 2,5 & 4,2 & 6,7 \\
\hline Manufaturas & 29,0 & 51,6 & 69,3 & 74,2 & 77,1 & 75,8 \\
\hline Aço e ferro & $0,7 \%$ & ND & $0,6 \%$ & $0,9 \%$ & $1,3 \%$ & $1,7 \%$ \\
\hline Químicos & $0,7 \%$ & ND & $2,7 \%$ & $4,5 \%$ & $6,6 \%$ & $8,2 \%$ \\
\hline $\begin{array}{l}\text { Máquinas e equipamentos } \\
\text { transporte }\end{array}$ & $5,8 \%$ & ND & $28,3 \%$ & $39,4 \%$ & $44,6 \%$ & $44,2 \%$ \\
\hline $\begin{array}{l}\text { Equipamentos de escritório e } \\
\text { telecom }\end{array}$ & $0,2 \%$ & $7,3 \%$ & $17,9 \%$ & $24,9 \%$ & $25,1 \%$ & $20,8 \%$ \\
\hline Produtos automotivos & $0,2 \%$ & ND & $1,1 \%$ & $1,7 \%$ & $4,7 \%$ & $8,3 \%$ \\
\hline Têxteis & $5,2 \%$ & $5,0 \%$ & $3,9 \%$ & $3,4 \%$ & $2,8 \%$ & $2,1 \%$ \\
\hline Vestuário & $5,8 \%$ & $11,6 \%$ & $11,5 \%$ & $7,0 \%$ & $5,0 \%$ & $2,9 \%$ \\
\hline
\end{tabular}

Fonte: Elaboração própria a partir de 1) GGCG, 2) GGDC, 3) OMC. 
Tabela 2A

Diversificação Comercial II: Exportação por intensidade tecnológica, 1980 a 2009, SEANICs (\% total exportado, US\$ correntes)

\begin{tabular}{l|c|c|c|c|c}
\hline \multirow{2}{*}{} & \multicolumn{5}{|c}{ Indonésia } \\
\cline { 2 - 6 } & 1985 & 1990 & $95 \_99$ & $00 \_05$ & $05 \_09$ \\
\hline Primários & 20,20 & 20,50 & 21,54 & 20,40 & 29,46 \\
\hline Energia & 68,60 & 43,80 & 26,09 & 27,04 & 29,14 \\
\hline Intensivos em trabalho e RN & 8,70 & 28,70 & 29,69 & 27,21 & 18,27 \\
\hline Baixa tecnologia & 0,20 & 1,70 & 2,64 & 2,32 & 3,11 \\
\hline Média-tecnologia & 0,10 & 1,00 & 4,03 & 6,96 & 8,72 \\
\hline Alta tecnologia & 1,70 & 3,20 & 10,03 & 16,05 & 11,29 \\
\hline Outros & 0,50 & 1,10 & 5,98 & 0,02 & 0,00 \\
\hline
\end{tabular}

Tabela 2B

\begin{tabular}{l|c|c|c|c|c}
\hline \multirow{2}{*}{} & \multicolumn{5}{|c}{ Malásia } \\
\cline { 2 - 6 } & 1985 & 1990 & $95 \_99$ & $00 \_05$ & $05 \_09$ \\
\hline Primários & 41,10 & 27,40 & 14,53 & 10,48 & 13,08 \\
\hline Energia & 31,50 & 18,30 & 8,58 & 11,42 & 17,04 \\
\hline Intensivos em trabalho e RN & 5,30 & 10,60 & 10,43 & 8,04 & 7,03 \\
\hline Baixa tecnologia & 1,60 & 2,70 & 2,53 & 2,32 & 3,57 \\
\hline Média-tecnologia & 3,40 & 6,90 & 9,76 & 10,09 & 10,68 \\
\hline Alta tecnologia & 16,60 & 31,70 & 53,18 & 56,62 & 45,42 \\
\hline Outros & 0,50 & 2,30 & 0,99 & 1,03 & 3,17 \\
\hline
\end{tabular}

Tabela $2 \mathrm{C}$

\begin{tabular}{l|r|r|r|r|r}
\hline & \multicolumn{5}{|c}{ Tailândia } \\
\cline { 2 - 6 } & 1985 & 1990 & $95 \_99$ & $00 \_05$ & $05 \_09$ \\
\hline Primários & 59,40 & 34,80 & 23,62 & 19,32 & 18,44 \\
\hline Energia & 1,40 & 0,80 & 4,80 & 5,53 & 9,23 \\
\hline Intensivos em trabalho e RN & 20,90 & 30,50 & 20,41 & 15,80 & 10,99 \\
\hline Baixa tecnologia & 2,30 & 2,70 & 3,38 & 3,80 & 5,14 \\
\hline Média-tecnologia & 7,90 & 7,70 & 14,82 & 19,65 & 24,02 \\
\hline Alta tecnologia & 4,50 & 18,60 & 31,15 & 33,31 & 31,51 \\
\hline Outros & 3,70 & 4,90 & 1,83 & 2,59 & 0,67 \\
\hline
\end{tabular}

Fonte: 1985 e 1990: Macedo e Silva (2008) a partir de Comtrade; 1995 a 2009: elaboração própria a partir da classificação de Macedo e Silva (2008) e Comtrade. 
Tabela 3A

Diversificação Produtiva: Composição do Valor de Transformação Industrial (US\$ correntes) e do Emprego da indústria de transformação (número de empregados) nos SEANICs, 2000 e média 20052012* (ISIC REV.3, em \%)

\begin{tabular}{l|c|c|c|c|c|c}
\hline \multirow{2}{*}{} & \multicolumn{5}{|c}{ Valor de Transformação Industrial } \\
\cline { 2 - 7 } & \multicolumn{2}{|c|}{ Indonésia } & \multicolumn{2}{c}{ Malásia } & \multicolumn{2}{c}{ Tailândia } \\
\cline { 2 - 7 } & 2000 & $\begin{array}{c}\text { Média } \\
05 / 12\end{array}$ & 2000 & $\begin{array}{c}\text { Média } \\
05 / 12\end{array}$ & 2000 & $\begin{array}{c}\text { Média } \\
05 / 12\end{array}$ \\
\hline Alimentos e bebidas & 11,2 & 17,4 & 13,5 & 16,2 & 7,7 & 10,7 \\
\hline Produtos de tabaco & 6,8 & 7,3 & 5,6 & 6,9 & 0,3 & 0,3 \\
\hline Têxteis & 10,1 & 5,6 & 15,1 & 11,7 & 2,3 & 0,9 \\
\hline Vestuário & 3,9 & 3,2 & 11,1 & 11,2 & 1,6 & 0,9 \\
\hline Couro e calçados & 2,7 & 2,0 & 6,4 & 5,1 & 0,2 & 0,2 \\
\hline Prod. Madeira (- móveis) & 5,7 & 2,6 & 9,0 & 5,6 & 3,9 & 2,5 \\
\hline Papel e produtos de papel & 3,8 & 6,0 & 2,5 & 2,8 & 2,0 & 1,4 \\
\hline Impressão e publicação & 2,8 & 1,0 & 1,3 & 1,2 & 2,0 & 1,9 \\
\hline Petróleo refinado, coque, combustível nuclear & 0,2 & 0,2 & 0,1 & 0,1 & 8,9 & 17,6 \\
\hline Químicos & 10,5 & 13,9 & 4,5 & 4,9 & 7,9 & 11,8 \\
\hline Borracha e plástico & 4,5 & 5,4 & 6,9 & 7,8 & 7,1 & 6,5 \\
\hline Prod. minerais não-metálicos & 0,0 & 4,1 & 0,0 & 3,9 & 4,7 & 3,5 \\
\hline Metais básicos & 3,8 & 3,6 & 1,4 & 1,4 & 2,8 & 3,5 \\
\hline Produtos de metal & 3,2 & 2,9 & 2,5 & 3,1 & 3,2 & 3,4 \\
\hline Máquinas e equipamentos & 1,0 & 1,9 & 1,1 & 1,7 & 3,4 & 3,2 \\
\hline Equip. escritório e contábil. & 0,0 & 1,2 & 0,0 & 1,2 & 5,3 & 10,7 \\
\hline Equipamentos elétricos & 3,8 & 2,9 & 1,7 & 2,0 & 3,6 & 2,4 \\
\hline Equip de Telecomunicações & 6,6 & 3,2 & 3,6 & 3,2 & 25,2 & 15,8 \\
\hline Inst. Médicos e óticos & 0,5 & 0,2 & 0,5 & 0,4 & 1,2 & 1,2 \\
\hline Veículos automotores & 5,9 & 9,5 & 1,2 & 2,0 & 2,7 & 3,3 \\
\hline Outros equip. de transporte & 6,8 & 5,3 & 1,6 & 1,7 & 1,2 & 1,5 \\
\hline Móveis, outros & 2,1 & 1,9 & 6,5 & 7,0 & 2,9 & 2,5 \\
\hline & & & & & & \\
\hline
\end{tabular}

Tabela 3B

\begin{tabular}{l|c|c|c|c|c|c}
\hline \multirow{2}{*}{} & \multicolumn{9}{|c}{ Emprego } \\
\cline { 2 - 8 } & \multicolumn{2}{|c|}{ Indonésia } & \multicolumn{2}{c}{ Malásia } & \multicolumn{2}{c}{ Tailândia } \\
\cline { 2 - 8 } & 2000 & $\begin{array}{c}\text { Média } \\
05 / 12\end{array}$ & 2000 & $\begin{array}{c}\text { Média } \\
05 / 12\end{array}$ & 2000 & $\begin{array}{c}\text { Média } \\
05 / 12\end{array}$ \\
\hline Alimentos e bebidas & 8,0 & 9,9 & 13,4 & 16,5 & 16,9 & 17,9 \\
\hline Produtos de tabaco & 0,6 & 0,2 & 4,3 & 1,3 & 0,5 & 0,3 \\
\hline Têxteis & 2,9 & 1,7 & 7,7 & 3,4 & 10,1 & 7,7 \\
\hline Vestuário & 4,8 & 3,0 & 2,8 & 3,1 & 6,3 & 8,8 \\
\hline Couro e calçados & 0,6 & 0,4 & 1,9 & 1,3 & 4,6 & 2,9 \\
\hline Prod. Madeira (- móveis) & 8,1 & 6,2 & 1,2 & 1,2 & 2,3 & 3,1 \\
\hline Papel e produtos de papel & 2,1 & 2,3 & 3,0 & 2,0 & 1,9 & 2,1 \\
\hline Impressão e publicação & 2,2 & 2,7 & 1,8 & 1,1 & 1,9 & 1,9 \\
\hline Petróleo refinado, coque, combustível nuclear & 0,5 & 0,5 & 6,1 & 2,0 & 0,3 & 0,4 \\
\hline
\end{tabular}




\begin{tabular}{l|c|c|c|c|c|c}
\hline \multirow{2}{*}{} & \multicolumn{9}{|c|}{ Emprego } \\
\cline { 2 - 7 } & \multicolumn{2}{|c|}{ Indonésia } & \multicolumn{2}{c}{ Malásia } & \multicolumn{2}{c}{ Tailândia } \\
\cline { 2 - 7 } & 2000 & $\begin{array}{c}\text { Média } \\
05 / 12\end{array}$ & 2000 & $\begin{array}{c}\text { Média } \\
05 / 12\end{array}$ & 2000 & $\begin{array}{c}\text { Média } \\
05 / 12\end{array}$ \\
\hline Químicos & 3,0 & 3,7 & 3,5 & 6,0 & 3,7 & 4,2 \\
\hline Borracha e plástico & 10,8 & 10,7 & 6,1 & 7,9 & 8,2 & 7,7 \\
\hline Prod. minerais não-metálicos & 3,8 & 3,7 & 6,4 & 3,8 & 5,6 & 4,6 \\
\hline Metais básicos & 2,7 & 2,9 & 2,3 & 3,9 & 1,7 & 2,1 \\
\hline Produtos de metal & 4,3 & 4,9 & 4,2 & 5,2 & 4,5 & 6,6 \\
\hline Máquinas e equipamentos & 3,3 & 3,5 & 3,8 & 4,7 & 3,6 & 3,6 \\
\hline Equip. escritório e contábil. & 4,6 & 8,8 & 5,5 & 6,3 & 2,6 & 4,3 \\
\hline Equipamentos elétricos & 5,0 & 3,5 & 5,1 & 3,7 & 4,9 & 3,3 \\
\hline Equip de Telecomunicações & 21,2 & 13,8 & 9,6 & 14,7 & 6,7 & 7,6 \\
\hline Inst. Médicos e óticos & 1,9 & 1,5 & 0,8 & 1,4 & 1,2 & 1,0 \\
\hline Veículos automotores & 2,2 & 3,2 & 6,6 & 12,9 & 4,4 & 5,1 \\
\hline Outros equip. de transporte & 1,4 & 1,5 & 0,5 & 1,7 & 0,9 & 1,1 \\
\hline Móveis, outros & 6,0 & 5,8 & 3,7 & 3,6 & 7,0 & 7,5 \\
\hline Fonyyyyyyyy
\end{tabular}

Fonte: Unido. *Dados obtidos descontínuos. Para Indonésia, média dos anos 2005, 2009 e 2011;

Malásia, média 2005, 2008 e 2012; Tailândia, média 2006 e 2011.

É ponto pacífico que o extraordinário crescimento dos SEANICs tenha sido viabilizado através da industrialização. De 1980 a 2010, a produtividade do trabalho medida em termos de valor adicionado (em termos reais) por trabalhador cresceu anualmente 2,3\% na Indonésia e Tailândia, e 3,6\% na Malásia, que claramente é o país que alcançou maior sofisticação dos SEANICs. De modo geral, a produtividade do trabalho na indústria de transformação cresceu mais do que em serviços e no setor primário. Mais além, o significativo crescimento da indústria de transformação desses países realmente elevou a participação dos mesmos nas exportações e no valor agregado da transformação industrial mundial; contudo, as parcelas dos recursos naturais dos SEANICS sobre o valor agregado mundial continuam superiores aos mesmos indicadores relativos à indústria da transformação (WDI, 2011). Também a heterogeneidade estrutural foi aliviada, apesar de ainda estar presente principalmente na Indonésia e Tailândia. Os determinantes dessa mudança estrutural são controversos, encontrando-se entre os mais citados, as exportações de manufaturas (especialmente das multinacionais) a partir das zonas especiais de exportação (ZEEs), o investimento direto estrangeiro (IDE), a política industrial ou até mesmo a liberalização econômica. Igualmente controversos também são os motivos para os limites do desenvolvimento industrial desses países.

Os efeitos de encadeamento têm sido apontados ao mesmo tempo como um dos mecanismos da diversificação e como um dos obstáculos para a sofisticação da matriz produtiva e exportadora dos SEANICs. No que concerne os mecanismos de diversificação, os efeitos de encadeamento são mostrados pela literatura discutindo- 
se especialmente os seguintes casos: na Malásia, o óleo de palmeira (Hazell; Hoell, 1983); na Tailândia, alimentos e joias (Doner, 2009); na Indonésia, compensados de madeira (Amsden, 2001); e o da exploração mineral por empresas públicas das indústrias de base nos dois últimos países (Rasiah, 2003). Já no que tange os obstáculos para a sofisticação, afirma-se recorrentemente que a indústria de manufaturas de exportação dos SEANICs não possui efeitos de encadeamento para o restante da oferta produtiva, constituindo-se também um empecilho para a superação da heterogeneidade estrutural.

Com o propósito avaliar a contribuição dos efeitos de encadeamento, especialmente dos setores exportadores mais expressivos, realizou-se uma análise a partir das matrizes insumo-produto (MIP) fornecidas pelos órgãos de estatísticas oficiais da Malásia e da Tailândia, e para a Indonésia pelo Banco de Dados Mundial de MIP (WIOD). Infelizmente os dados não são homogêneos, pois cada matriz tem uma quantidade de produtos e atividades diferente, e as disponibilidades de ano não são as mesmas. A despeito dessas dificuldades, apresenta-se na Tabela 4 uma síntese dos resultados obtidos no cálculo dos efeitos para frente e para trás, e também o multiplicador do produto para os anos de 1995 e 2005 (exceto para Malásia, pois o governo somente apresenta a MIP de 2005).

Dentre as atividades com maiores efeitos de encadeamento para trás e multiplicadores do produto na Malásia, destacam-se transporte aéreo e indústrias de processamento de recursos naturais ou de baixa tecnologia (luvas e processamento de borracha, óleos e gorduras, seguidos por carne, acabamento de têxteis, mineração de metais, cimento, cal e gesso). Tanto derivados de borracha quanto de óleos são indústrias desenvolvidas conforme o argumento da staple theory, já que a borracha e depois a palmeira foram os recursos naturais mais explorados pelo setor primárioexportador desde o pós-guerra. Inclusive, óleo de palmeira, processamento e produtos da borracha são atividades que apresentam altos efeitos de encadeamento para frente. Na Indonésia, tanto em 1995 quanto em 2005 as atividades de maior encadeamento para trás e multiplicador de produto foram as indústrias mais tradicionais, intensivas em mão-de-obra e matéria-prima, como alimentos/ bebidas e tabaco, couro, têxteis, produtos da madeira, papel e celulose, borrachas e plásticos; seguidos por produtos químicos, hotéis e restaurantes, e equipamentos elétricos e óticos. Em termos de encadeamento para frente, em 2005 os efeitos mais expressivos estavam relacionados ao setor de serviços (setor imobiliário, correios e telégrafos), infraestrutura (eletricidade, gás e abastecimento de água) e indústrias processadoras de recursos naturais como papel e celulose, produtos da madeira, mineração. Em 1995 a importância dessas indústrias em termos de efeitos para frente era maior relativamente a 2005 e aos serviços (setor imobiliário, correios e telégrafos), o que indica que nesta década o setor terciário passou a contribuir mais para a dinâmica da renda. E na Tailândia, construção, alimentos, têxteis, pecuária, borrachas e plásticos, 
minerais e serviços (transporte e hotéis e restaurantes), tiveram efeitos de encadeamento para trás e multiplicadores mais expressivos em 2005, ao passo que mineração, florestais, minerais metálicos básicos e infraestrutura tiveram efeitos de encadeamento para frente mais fortes.

Tabela 4A

Efeitos de encadeamento para trás e para frente, multiplicadores do produto, por atividade SEANICs, 1995 e 2005

\begin{tabular}{l|c|c|c}
\hline \multirow{2}{*}{ Malásia } & \multicolumn{2}{|c}{2005} \\
\cline { 2 - 4 } & P/ trás & P/ frente & $\begin{array}{c}\text { Multiplicador } \\
\text { Produto }\end{array}$ \\
\hline Efeito máximo & 1,52 & 1,99 & 2,88 \\
\hline Agricultura & 0,79 & 1,37 & 1,5 \\
\hline Borracha & 0,74 & 0,79 & 1,4 \\
\hline Equipamento elétrico & 0,88 & 0,75 & 1,67 \\
\hline Equips. De escritório, computação & 0,79 & 0,66 & 1,5 \\
\hline Equips. Médicos, cirúrgicos éticos & 0,92 & 0,66 & 1,74 \\
\hline Lâmpadas elétricas e materiais de iluminação & 1 & 1,04 & 1,9 \\
\hline Luvas de borracha & 1,51 & 0,83 & 2,85 \\
\hline Óleo cru e gás natural & 0,69 & 1,08 & 1,31 \\
\hline Óleo de Palmeira & 0,82 & 1,63 & 1,55 \\
\hline Óleos e gorduras & 1,46 & 1,14 & 2,75 \\
\hline Processamento de borracha & 1,26 & 1,51 & 2,38 \\
\hline Produtos da borracha & 1,06 & 1,49 & 2 \\
\hline Refino de petróleo & 1,1 & 1,33 & 2,08 \\
\hline Serviços de computador & 0,91 & 1,37 & 1,71 \\
\hline TV, Rádio receptores e transmissores & 0,93 & 0,83 & 1,75 \\
\hline Efeito Mínimo & 0,56 & 0,55 & 1,05 \\
\hline
\end{tabular}

Tabela 4B

\begin{tabular}{l|c|c|c|c|c|c}
\hline \multirow{2}{*}{ Indonésia } & \multicolumn{3}{|c|}{1995} & \multicolumn{3}{c}{2005} \\
\cline { 2 - 7 } & Para trás & Para frente & $\begin{array}{c}\text { Multiplicador } \\
\text { Produto }\end{array}$ & Para trás & $\begin{array}{c}\text { Para } \\
\text { frente }\end{array}$ & $\begin{array}{c}\text { Multiplicador } \\
\text { Produto }\end{array}$ \\
\hline Efeito máximo & 1,29 & 1,58 & 2,06 & 1,16 & 1,53 & 1,84 \\
\hline $\begin{array}{l}\text { Agricultura, caça, pesca, } \\
\text { floresta }\end{array}$ & 0,77 & 1,14 & 1,23 & 0,8 & 1,18 & 1,28 \\
\hline Alimentos, bebidas, tabaco & 1,14 & 0,78 & 1,82 & 1,16 & 0,93 & 1,84 \\
\hline Borrachas e plásticos & 1,15 & 0,9 & 1,84 & 1,03 & 0,86 & 1,63 \\
\hline Couro & 1,08 & 0,84 & 1,72 & 1,16 & 0,85 & 1,83 \\
\hline $\begin{array}{l}\text { Eletricidade e estrutura } \\
\text { sanitária }\end{array}$ & 1,02 & 1,37 & 1,64 & 1,1 & 1,37 & 1,74 \\
\hline Hotéis e restaurantes & 1,13 & 0,75 & 1,8 & 1,01 & 0,92 & 1,61 \\
\hline Mineração & 0,72 & 0,74 & 1,15 & 0,73 & 1,22 & 1,16 \\
\hline
\end{tabular}


Tabela 4B - Continuação

\begin{tabular}{l|c|c|c|c|c|c}
\hline \multirow{2}{*}{ Indonésia } & \multicolumn{3}{|c|}{1995} & \multicolumn{3}{c}{2005} \\
\cline { 2 - 7 } & Para trás & Para frente & $\begin{array}{c}\text { Multiplicador } \\
\text { Produto }\end{array}$ & Para trás & $\begin{array}{c}\text { Para } \\
\text { frente }\end{array}$ & $\begin{array}{c}\text { Multiplicador } \\
\text { Produto }\end{array}$ \\
\hline Minerais metálicos & 0,98 & 0,87 & 1,57 & 1,04 & 0,88 & 1,64 \\
\hline Minerais não-metálicos & 1,07 & 1,28 & 1,71 & 1,01 & 1,21 & 1,6 \\
\hline Minerais não-metálicos & 1,07 & 1,28 & 1,71 & 1,01 & 1,21 & 1,6 \\
\hline Papel e celulose & 1,22 & 1,58 & 1,95 & 1,1 & 1,23 & 1,74 \\
\hline Petróleo refinado & 0,97 & 0,9 & 1,55 & 0,83 & 0,94 & 1,31 \\
\hline Produtos da madeira & 1,23 & 1,25 & 1,97 & 1,1 & 1,22 & 1,74 \\
\hline Setor imobiliário & 0,77 & 0,95 & 1,24 & 0,95 & 1,53 & 1,5 \\
\hline Têxteis & 1,29 & 1,09 & 2,06 & 1,12 & 0,87 & 1,78 \\
\hline Efeito Mínimo & 0,72 & 0,62 & 1,15 & 0,73 & 0,66 & 1,16 \\
\hline
\end{tabular}

Tabela 4C

\begin{tabular}{|c|c|c|c|c|c|c|}
\hline \multirow[b]{2}{*}{ Tailândia } & \multicolumn{3}{|c|}{1995} & \multicolumn{3}{|c|}{2005} \\
\hline & Para trás & Para frente & $\begin{array}{c}\text { Multiplicador } \\
\text { Produto }\end{array}$ & Para trás & $\begin{array}{l}\text { Para } \\
\text { frente }\end{array}$ & $\begin{array}{c}\text { Multiplicado } \\
\text { r Produto }\end{array}$ \\
\hline Efeito máximo & 1,32 & 1,67 & 2,19 & 1,3 & 1,54 & 2,29 \\
\hline Agricultura & 0,79 & 1,17 & 1,31 & 0,84 & 1,14 & 1,48 \\
\hline Alimentos & 1,3 & 0,82 & 2,16 & 1,27 & 0,84 & 2,24 \\
\hline Bebidas e tabaco & 0,91 & 0,72 & 1,51 & 0,94 & 0,69 & 1,65 \\
\hline Borrachas e plásticos & 1,12 & 0,91 & 1,86 & 1,13 & 0,92 & 2 \\
\hline Construção & 1,19 & 0,55 & 1,97 & 1,3 & 0,56 & 2,29 \\
\hline $\begin{array}{l}\text { Eletricidade e estrutura } \\
\text { sanitária }\end{array}$ & 1,03 & 1,25 & 1,7 & 1,07 & 1,22 & 1,88 \\
\hline Florestais & 0,66 & 1,21 & 1,09 & 0,72 & 1,44 & 1,26 \\
\hline Hotéis e restaurantes & 1,14 & 0,67 & 1,88 & 1,1 & 0,66 & 1,94 \\
\hline Mineração & 0,75 & 1,67 & 1,24 & 0,65 & 1,54 & 1,15 \\
\hline Minerais metálicos básicos & 0,8 & 1,31 & 1,33 & 0,79 & 1,3 & 1,4 \\
\hline Minerais não-metálicos & 1,1 & 1,11 & 1,82 & 1,09 & 0,95 & 1,93 \\
\hline Papel e celulose & 1,06 & 1,23 & 1,76 & 1,02 & 1,16 & 1,8 \\
\hline$\underline{\text { Pecuária }}$ & 1,32 & 1,22 & 2,19 & 1,21 & 1,17 & 2,14 \\
\hline Químicos & 0,86 & 1,25 & 1,43 & 0,9 & 1,18 & 1,59 \\
\hline Têxteis & 1,28 & 0,91 & 2,12 & 1,22 & 0,92 & 2,16 \\
\hline Efeito Mínimo & 0,66 & 0,55 & 1,09 & 0,65 & 0,56 & 1,15 \\
\hline
\end{tabular}

Fontes: Indonésia: WIOD; Malásia (120 atividades): Departamento de Estatísticas (IOT 2005, 33 atividades); Tailândia: National Economic and Social Development Board (IOTs 1995 e 2005, 26 atividades).

Ou seja, nos três países, as indústrias de processamento de recursos naturais e mão-de-obra intensivas e alguns segmentos de serviços especializados (construção, transporte, setor imobiliário e turismo) são as atividades com maior efeito de encadeamento e multiplicadoras de produto, sendo que da década de '90 para a de 
'00, a importância do primeiro grupo diminuiu em relação ao segundo, de serviços. Assim, de fato os efeitos de encadeamento se comprovaram importantes de certas indústrias processamento de recursos naturais exportados, tendo contribuído para a diversificação destas economias. Este é o caso de alimentos, têxteis e papel e celulose (Indonésia e Tailândia), processados de madeira (Indonésia), de borracha (Malásia e Indonésia) e de óleos (Malásia), e até mesmo processados de minérios (todos). Por sua vez, atividades primárias em si, agricultura e extrativismo, atualmente apresentam resultados de encadeamento mais fracos - como arroz, borracha e vegetais na Malásia e mineração nos outros dois países. Portanto, a evolução da produção de recursos naturais para o seu processamento - à semelhança do desenvolvimento da indústria processada de alimentos e produtos diários na Europa no século XIX (Senghaas, 1985) - é interessante para a diversificação em geral da economia. Exceção deve ser feita aos derivados do petróleo e do gás, que ainda apresentam baixo encadeamento.

Outro argumento corroborado na análise é o de que as principais atividades manufatureiras de exportação, relacionadas aos setores de média e alta tecnologia (principalmente na Malásia e na Tailândia), têm fracos efeitos de encadeamento nas economias domésticas. Essas atividades - entre as quais sobressaem os eletroeletrônicos, circuitos elétricos e telecomunicações - tampouco surgiram da industrialização por etapas, isto é, não resultaram de efeitos de transbordamento da substituição de importações. Advieram das estratégias de realocação e terceirização das grandes firmas transnacionais e das políticas de atração do Estado, localizandose em geral nas ZEEs. Conforme se observa na MIP da Malásia (mais completa), nos SEANICs essas atividades contribuem pouco para o desenvolvimento a jusante de sua estrutura produtiva (Tabela 5) - ao contrário, nos NICs tais atividades possibilitaram a sofisticação (Rasiah, 2003).

Tabela 5

Efeitos de encadeamento e multiplicador de produto do setor de eletroeletrônicos da Malásia, 2005

\begin{tabular}{l|c|c|c}
\hline \multicolumn{1}{c|}{ Atividade } & Para trás & $\begin{array}{c}\text { Para } \\
\text { frente }\end{array}$ & $\begin{array}{c}\text { Multiplicador } \\
\text { Produto }\end{array}$ \\
\hline Máquinas para objetivos especiais & 0,92 & 0,92 & 1,73 \\
\hline Eletrodomésticos & 0,89 & 0,58 & 1,68 \\
\hline Maquinário para escritório, computadores, calculadoras & 0,79 & 0,66 & 1,50 \\
\hline Máquinas e acessórios elétricos & 0,88 & 0,75 & 1,67 \\
\hline Outras máquinas elétricas & 1,02 & 0,60 & 1,93 \\
\hline Fios e cabos & 0,87 & 1,07 & 1,65 \\
\hline Lâmpadas elétricas e equipamentos de iluminação & 1,00 & 1,04 & 1,90 \\
\hline Dispositivos semicondutores, tubos, placas de circuito & 0,96 & 0,78 & 1,82 \\
\hline Receptores de TV, Rádio e Transmissores & 0,93 & 0,83 & 1,75 \\
\hline Aparelhos médicos, cirúrgicos e ortopédicos & 0,92 & 0,66 & 1,74 \\
\hline Fon
\end{tabular}

Fonte: Depto. de Estatísticas da Malásia (IOT, 2005, 33 atividades). 
Conclui-se que, nos SEANICs, a diversificação produtiva contou em alguma medida com os efeitos de encadeamento dos setores de recursos naturais. Contudo essa passagem requereu instituições (como na staple theory ou na teoria estruturalista) que ajudaram a industrialização por substituição de importações (ISI) na direção dos setores de processamento de recursos naturais ou de mão-de-obra intensivas. Porém, a diversificação relativa à industrialização orientada para as exportações (IOE) originou fracos efeitos de encadeamento para o restante da economia e surgiu em resposta exclusivamente a fatores institucionais: da parte do governo, às políticas industriais e ao regime macroeconômico; da parte das empresas, suas estratégias de produção a menores custos e mercado. Estes fatores, por sua vez, não enfatizaram os efeitos de encadeamento que pudessem contribuir para a superação da heterogeneidade estrutural. As principais instituições associadas aos dois casos são apresentadas a seguir.

\section{As instituições relacionadas à diversificação produtiva e comercial na Indonésia, Malásia e Tailândia}

Diferentemente da abordagem da NEI, as instituições são tomadas nesta perspectiva de modo amplo, "como padrões socialmente compartilhados de comportamento e/ ou de pensamento" (Dequech, 2009 apud Dequech, 2011, p. 607). A vantagem dessa abordagem é que a dimensão social se sobrepõe à individual, considerando que as instituições podem impactar a cognição e as motivações dos indivíduos (e não somente que os indivíduos edificam as instituições). Mais além, essa conceptualização permite apreender a retroalimentação entre as instituições e as relações de poder, de forma que a economia das instituições espelhe a economia política de uma localidade. ${ }^{16}$ Como a gama de instituições de um país é muito diversificada, a análise das instituições mais correlatas à promoção de diversificação produtiva e comercial, em particular, às voltadas para o aproveitamento dos efeitos de encadeamento para a superação da heterogeneidade estrutural, se centrará nas instituições de coordenação e administração, de aprendizado e inovação e de transferências sociais e distribuição - conforme sugere Chang (2006).

Primeiramente, é preciso compreender os interesses políticos e econômicos que nortearam a ação do Estado. Ao longo do pós-guerra, o sistema político estatal sustentou quatro grupos de interesses principais: o do setor primário-exportador (de propriedade doméstica, em sua maior parte); o da industrialização, tanto por substituição de importações (de caráter mais doméstico) quanto orientada para exportações (com forte presença de empresas e bancos multinacionais estrangeiros,

(16) “As instituições são em parte mantidas por relações de poder; no caso específico das organizações, trata-se de instituições que são em parte definidas por essas relações de poder, na forma de relações hierárquicas. Por outro lado, sobretudo através de sua presumida legitimidade ou inevitabilidade, as instituições ajudam a sustentar relações de poder" (Dequech, 2011, p. 608-609). 
principalmente japoneses e americanos); o bélico-militar (sob a liderança dos EUA, dada a importância geopolítica da região, principalmente durante a guerra-fria) e o religioso (ainda que nas regiões convivam uma grande diversidade étnica e cultural, predominam o islamismo na Indonésia e na Malásia e o budismo na Tailândia). Nos três países, e mais nitidamente na Indonésia, o poder das oligarquias locais resistiu e durou ao longo do período, não somente porque se mantiveram economicamente relevantes, mas também porque o aparato patrimonialista ${ }^{17}$ ou "cronista" ${ }^{18}$ do Estado os protegeu.

$\mathrm{Na}$ Indonésia, a "Nova Ordem" foi conduzida militarmente pelo General Suharto, brutal - contudo não assumidamente ditatorial, porque parlamentarista. ${ }^{19}$ Após mais de trinta anos no poder, a crise econômica ao final do século foi o estopim para a desmontagem do sistema político e a queda do líder em 1999. A democratização apenas reorganizou as relações de poder incubadas no regime anterior, pois as oligarquias que as comandavam permaneceram no poder. Tal continuidade aconteceu porque as oligarquias conseguiram costurar o tecido político em dois sentidos principais: (i) edificando impérios de negócios complexos em parceria com os chineses e investidores externos, (ii) assegurando o acesso dos mercados financeiros globais através de empréstimos financeiros e da capitalização de suas empresas em bolsa de valores (Hadiz; Robinson, 2004).

Em 1971, o governo parlamentar da Malásia lançou a "Nova Política Econômica", que durou até 1990, possibilitou dois movimentos importantes: a industrialização e a maior participação dos bumiputras (população de origem malaia) nos negócios. A administração de Mahathir, de 1981 a 2003, foi bastante centralizada e nacionalista, ainda que tenha permitido privatizações e um maior grau de abertura econômica (JOMO, 1999). Vale notar o país permaneceu sob o governo do partido UMNO (United Malays National Organization) da independência até os dias de hoje.

Em comparação aos outros países do SEANICs, o Estado da Tailândia foi historicamente mais homogêneo em termos étnicos, políticos e religiosos. Embora

(17) Patrimonialismo é um termo amplo que se expressou diferentemente em cada contexto, figurando um caráter "administrativo" na Tailândia e na Malásia, e "burocrático" na Indonésia (Hutchcroft, 1998). Isto é, nos primeiros casos o patrimonialismo se dava na esfera parlamentar, com ascendência do Estado - liderado por uma classe burocrática coesa -, sobre as classes de negócios. No caso da Indonésia, o patrimonialismo se fazia na esfera da burocracia do governo, com distribuição de privilégios dentro do próprio Estado, com ascendência dos interesses de negócios sobre a burocracia não coesa do governo.

(18) 'Utiliza-se 'cronistas’ para descrever aqueles cujas posições são particularmente favorecidas pelo regime atual, independentemente de suas origens. Um 'oligarca' não pode ser um cronista atual, mas em ambos os casos estabeleceram sua fortuna em repartições anteriores" (Hutchcroft, 1998, p. 435, tradução nossa).

(19) As eleições eram orquestradas (e manipuladas) pelo partido do Estado - o Golkar, outro pilar de sustentação do governo (University of Cambridge, 1992). O governo aniquilou centenas de milhares de comunistas e rebeldes separatistas na região do Timor Leste. Para uma análise completa, ver Roosa (2006). 
tenha se mantido independente, o sistema político tailandês esteve sempre compromissado com poderes externos, seja a Inglaterra, o Japão ou os EUA. O grupo diversificado de negócios chineses mais tarde seria o núcleo de vários setores da indústria tailandesa, principalmente a têxtil (destacando as empresas Saha Union e Thai Blanket). O golpe em 1957 iniciou o regime militar, com duração até 1988. A democratização manteve a centralização, principalmente entre 2001 e 2006, durante o governo de Thaksin Shinawatra, deposto por novo golpe militar. Logo a democracia retornou, em um clima político instável, com protestos frequentes entre os dois principais grupos políticos da atualidade (Partido do Poder do Povo, de Thaksin; e a Aliança do Povo pela Democracia) (Doner, 2009).

Portanto, mesmo depois da substituição dos líderes decenários ao final do século passado, a coalizão de poder pouco se alterou nos três países - continuando a prevalecer uma aliança que combina os interesses econômicos e financeiros externos, do setor exportador de recursos naturais, do setor industrial para o mercado doméstico e para a plataforma de exportações. É razoável supor, portanto, que tal aliança direcionou a diversificação produtiva e exportadora dessas economias através de instituições como política industrial, regime de propriedade, financiamento e ZEEs. Sem embargo, em virtude da pequenez dos mercados domésticos nos anos oitenta, a indústria manufatureira somente cresceu e diversificou para valer após incentivar a industrialização orientada para as exportações. A controvérsia sobre o viés liberal ou intervencionista do sucesso da integração dos SEANICs ao comércio internacional de mercadorias e capitais devese também às próprias ambiguidades e contradições das políticas industriais daqueles governos. Mas conforme Athukorala e Devadason (2011), o grau de abertura dos diferentes setores em cada um dos países não foi total até 2010. A Indonésia é um país quase totalmente aberto na maioria dos setores, exceto mídia, telecomunicações e transporte. A Malásia somente é totalmente aberta na indústria de transporte e de transformação leve, sendo a mais nacionalizada em telecomunicações, eletricidades e até mesmo setor bancário e seguros. A Tailândia parece ser a mais fechada, com grau de abertura médio inferior a 50\% na maioria dos setores.

No setor de recursos naturais dos SEANICs, em geral o Estado desempenhou papel central para o aproveitamento de efeitos de encadeamento no sentido da evolução das atividades extrativas e agrícolas para as de processamento de recursos naturais e alimentos, que em geral exigiam nível tecnológico mais simples. No caso da Indonésia, o exemplo mais citado da atuação do Estado é a sua atuação nas atividades relacionadas aos produtos de madeira (Amsden, 2001; Hadiz; Robinson, 2004; Rasiah, 2003). Ainda que a questão tenha tido também um componente político importante (enfrentamento de oligarquias da oposição, de acordo com Jomo, 1999), a proibição de exportação de madeira crua possibilitou o desenvolvimento a 
jusante dessa indústria ${ }^{20}$. Uma das medidas nesse sentido foi imposta aos bancos estrangeiros na Indonésia, seja por filiais ou por joint ventures (empreendimentos conjuntos), que tinham de destinar ao setor exportador metade dos empréstimos e ao menos $80 \%$ dos fundos para operações no estrangeiro (offshore). Outra medida foi o controle exercido pelo governo sobre o padrão do produto das concessionárias, aos moldes dos controles de qualidade no Japão (Amsden, 2001). O governo incentivou que os produtores formassem a APKINDO, uma associação exportadora que posteriormente chegou a ser formadora do preço internacional de madeira compensada. Então, de 1980 para 1986 a parcela de compensados nas exportações de manufaturas se elevou de $10 \%$ para $36 \%$ (Rasiah, 2003, p. 28). Depois essa parcela reduziu relativamente em 1991 para 18\%, não pelo arrefecimento da produção, mas pelo grande crescimento das exportações de outras manufaturas, conforme discutido anteriormente. Ao final dos anos 2000, o setor já não atingia 3\% do total exportado.

O paralelo da indústria de compensados da Indonésia é a de óleo de palmeira da Malásia, que também alavancou graças ao impulso do Estado para promoção de exportações e avanços tecnológicos que a tornaram uma indústria de ponta ${ }^{21}$. $\mathrm{O}$ refino foi incentivado basicamente pelo fato da exportação de óleo cru ter sido pesadamente tarifada enquanto a de óleo processado recebia uma série de benefícios (Fold; Whitfield, 2012). Outros setores importantes de processamento de recursos naturais foram os produtos de madeira, minérios (como o estanho) e o petróleo. Nesse último, desde o Ato do petróleo de 1974, o governo federal lidera a contratação para a exploração e produção de petróleo através da Petronas, utilizando sua política de compras para desenvolver a indústria a jusante, principalmente. De modo geral, as empresas estatais estavam a cargo de refinar petróleo e realizar investimentos em nafta, produzindo etileno e propileno a serem processados por empresas privadas do setor químico (produtores de plástico, fibras sintéticas, borracha, têxteis sintéticos etc.). Medidas similares propiciaram também efeitos de encadeamento na indústria de petróleo da Indonésia, que se enfraqueceu nos anos oitenta devido ao esgotamento

(20) Em um primeiro momento, o governo tentou proibir exportação da madeira “crua", mas como o então GATT protestou, a proibição foi substituída por tarifas pesadas. Os destinos da matéria-prima eram as processadoras e re-exportadoras de Taiwan e Coréia. Através da associação, das políticas coordenadas e da aprovação direta de vendas no exterior, o governo conseguiu manter uma ação coordenada cartelista dos produtores indonésios. O sucesso das exportações de compensados foi replicado pela Malásia e Filipinas, apertando a competição e busca por ganhos de tecnologia (Amsden, 2001, p. 177-178).

(21) A especialização inicial não se deveu às dotações de recursos, pois a planta é originalmente africana, tendo sido introduzida nas regiões de clima tropical úmido pelos europeus. Até os anos 2000, as plantations de palmeiras eram de propriedade estatal, enquanto os moinhos para fazer o óleo cru eram independentes e localizados perto das áreas de cultivo porque o produto tem de ser tratado no máximo 24 horas após a colheita. O refino para aplicações industriais teve tecnologia desenvolvida nacionalmente e, mais importante, nas áreas rurais - devido à necessidade inicial de proximidade da produção. O Estado concedeu uma série de benefícios fiscais e creditícios para que as refinarias pudessem ser estabelecidas, principalmente de 1980 em diante (Fold ; Whitfield, 2012). 
das reservas e que voltou a crescer a partir do final dos anos noventa dado o desenvolvimento das técnicas de exploração. Em tempo, o exemplo do desenvolvimento tecnológico dessas grandes corporações do petróleo corroboram a crítica da primeira seção sobre a possibilidade do setor primário possibilitar efeitos de encadeamento que propiciem a sofisticação.

E na Tailândia, as indústrias de maior porte que estariam relacionadas à produção de recursos naturais são as de alimentos e de joias, implantadas nos processos de ISI - mas que conseguiram exportar também. Antes uma economia agrária altamente dependente do arroz, o país se tornou o exportador de alimentos mais importante do Sudeste asiático (Crispin; Goad, 2000 apud Doner, 2009). Conforme se discute mais adiante, o desenvolvimento da indústria processadora de agrícolas contou com incentivos como isenções de impostos de três a sete anos sobre empresas, valor adicionado e exportações, créditos de importação de maquinários e fatores de produção, com subsídio de energia e transporte (Rasiah, 2003, p. 40).

Alavancada nos anos cinquenta e sessenta, a industrialização por substituição de importações é anterior ao modelo exportador de manufaturas nos três países dos SEANICs, apoiada por empresas públicas, principalmente em infraestrutura e indústria de base. A aquisição de tecnologias nas estatais constituiuse um mecanismo importante de transbordamento da atividade industrial. Não foram raros os casos em que as políticas de compras se valiam das licenças de fornecedores internacionais, para depois difundir para as firmas menores dentro dos grupos empresariais ou para sublocatários de outras indústrias "sem as barreiras legais" de joint ventures. (Amsden, 2001, p. 239).

$\mathrm{Na}$ Indonésia, a partir da década de sessenta, a ISI floresceu através de restrições à propriedade estrangeira e de medidas que preteriram os pequenos negócios da população chinesa em benefício dos locais de origem indígena. O investimento das empresas públicas em um massivo programa de construção de infraestrutura e de industrialização pesada - aço, petroquímicos, fertilizantes, alumínio, cimento - foi financiado com petrodólares. Com a queda do preço do barril, em 1981-1982 e depois novamente em 1985-1986, o governo pôs em curso reformas que flexibilizaram o protecionismo, permitindo a entrada de capital externo, inclusive em setores estratégicos e no financeiro. Como Hadiz e Robinson (2004) defendem, a liberalização foi parcial, de forma que o Estado manteve o intervencionismo porque instituições "guardiãs" dos interesses do governo, ou melhor, das oligarquias no poder, foram mantidas nas áreas de alocação de licenças, contratos, distribuição e crédito. Além disso, certos setores muito estratégicos demoraram a ser liberalizados (como o de automóveis, de alimentos, petróleo e florestas). As privatizações foram lentas e não generalizadas. E os setores liberalizados, em larga medida, foram "apropriados" pelas famílias e pelos 
cronismos que já se apoderavam dos mesmos enquanto governo (Hadiz; Robinson, 2004).

Por sua vez, na Malásia, a partir da independência nacionalizaram-se parte das empresas privadas (principalmente inglesas), inclusive a Petronas (Permodalan Nasional Berhad). Em 1975, promulgou-se o ato de coordenação industrial, o qual impôs requerimentos étnicos (a favor dos bumiputras) sobre as firmas, dependendo do seu tamanho e orientação de mercado: firmas para o mercado doméstico deviam ter propriedade nacional, mas a regra não se aplicava para firmas que exportavam mais de $80 \%$ da produção (eximindo, assim, as firmas multinacionais que operavam no país como plataforma de exportação). Assim, as firmas para o mercado interno, a exceção dos setores de bebidas e tabaco, eram predominantemente de propriedade local (Rasiah, 2003). Desde os anos oitenta, o governo de Mahathir aumentara a centralização da produção das indústrias pesadas (automóveis, cimento e siderurgia) através da Corporação de Indústrias Pesadas da Malásia, que se tratava de jointventures entre o Estado e o capital privado (em geral externo), protegidas com incentivos como subsídios e isenções tarifárias.

Desde cedo, o governo tailandês se engajou na questão do financiamento do setor privado principalmente via empréstimos com baixos juros. A corporação industrial financeira da Tailândia, criada em 1959 para financiar projetos de grandes empresas, era de capital estatal e de bancos privados externos. Essa ação coordenada entre bancos e investidores, já desde a década de sessenta, foi crucial para transformar, modernizar e diversificar, primeiramente, a estrutura produtiva agrícola, encorajando a formação de grandes conglomerados de agronegócio, destacando as atividades têxtil, eletrônica e bens de capital (Doner, 2009). Então, o Estado foi fundamental nesse ponto por propiciar agências macroeconômicas e bancos comerciais que, mesmo que com clientelismos, propiciaram o desenvolvimento de certos grupos dos setores industrial e agrário que proporcionaram crescimento econômico - notadamente o de automóveis ${ }^{22}$ e de tecnologia da informação ${ }^{23}$.

Os mecanismos de financiamento tinham como núcleo os bancos de investimento internos. Os bancos públicos de todos os países determinavam prioridades e alocavam rendas, com injeções de crédito e de subsídios na economia, em geral para projetos estratégicos de empresas estatais e privadas. Por exemplo, na Indonésia, em 1983, o banco central mais os bancos públicos eram responsáveis por mais de $70 \%$ do crédito da economia, e $60 \%$ no início dos anos noventa (Hadiz; Robinson, 2004). Naquele país os fundos de pensão contribuíram para o crédito e

(22) O país chegou a ser chamado de "Detroit da Ásia" (Doner, 2009).

(23) Como o setor de drivers de disco da Tailândia, do qual a empresa nacional Seagate se tornou a maior empregadora do país. Seu crescimento contou com P\&D através de um consórcio de universidades e o Instituto de Tecnológico asiático (de iniciativa japonesa) baseado em Bangkok (Idem). 
um forte banco de desenvolvimento, o Bapindo. O Banco Central da Indonésia também fazia financiamento diretamente para empresas estatais como a Pertamina e a Aço Krakatau (Amsden, 2001). Por sua vez, na Malásia, houve quatro bancos de desenvolvimento, destacando-se o Bank Industri - que entrava de sócio em projetos industriais, sendo também administrador e consultor financeiro dos clientes, monitorando os resultados (Abidin, 2001). No início dos anos oitenta, os bancos nacionais possuíam $62 \%$ dos ativos totais do setor bancário malaio, sendo que o Banco Bumiputra Malásia Berhad - de propriedade estatal - era o maior banco comercial. O governo era também o acionista mais importante dos bancos privados, entre eles o Banco Malaio Berhad e Corporação Bancária Malaia Unida) (Amsden, 2001). Já os bancos de desenvolvimento tailandeses ofereciam crédito para projetos de longo prazo, enquanto os bancos comerciais, estabelecidos por casas comerciais sino-chinesas, atuavam no segmento de curto prazo. Também ali o governo era o principal acionista dos maiores bancos privados. O banco de desenvolvimento Corporação Financeira Industrial da Tailândia. Era também uma ferramenta importante para o Board of Investments (BOI, Conselho de Investimentos) ${ }^{24}$, instituição notável de planejamento para o desenvolvimento industrial. Vale notar que na Tailândia aconteceu algo diferente do que nos outros países dos SEANICs: o banco de desenvolvimento tornou-se mais importante nos anos noventa.

Embora os Estados dos SEANICs não incentivassem a estratégia de "líderes nacionais" como no Japão e na Coréia, alguns grupos públicos nacionais lograram gerar e transferir tecnologia, fortalecer procedimentos gerenciais e investir em P\&D, tornando-se um centro de referência para o treinamento de funcionários e empreendedores, que alimentariam também o setor privado. Na sua origem, a ideia de nacionalizar os recursos naturais era uma estratégia política contra ameaças externas, principalmente chinesas. Nos anos noventa, houve uma onda de privatizações (a começar pelo setor financeiro), que teve alcances diferentes entre os países dos SEANICs. Após a privatização, a nova forma do Estado guardar certo controle sobre os setores estratégicos foi através das agências regulatórias.

Por fim, sobre as instituições associadas à industrialização orientada para exportações (IOE), primeiramente é preciso lembrar o contexto externo de custos crescentes e valorização do câmbio nos NICs e no Japão, já em plena evolução da globalização produtiva. Os SEANICs e seus incentivos de política industrial emergiram como uma alternativa muito interessante para as multinacionais reorganizarem suas cadeias produtivas. Inicialmente, as firmas estrangeiras se inseriram ali através de subcontratações de firmas nos setores intensivos em mão-

(24) Os benefícios do BOI, segundo Amsden (2001) eram concedidos tendo como contrapartida padrões de desempenho relacionados às metas de exportação, conteúdo local, tetos da relação dívida/passivo, propriedade nacional, escala mínima de operação, obrigações dos cronogramas de investimento, distribuição regional, e até mesmo qualidade dos produtos e critérios ambientais. 
de-obra, Posteriormente, foram progressivamente aderindo ao investimento direto (IDE), principalmente nas ZEEs. As primeiras ZEEs dos SEANICs foram na Malásia, oficialmente a partir do ato de 1968 (mas na prática após 1972), na Tailândia após 1979, e na Indonésia após 1986 - com apoio explícito de agências multilaterais como o Banco de Desenvolvimento Asiático, o Banco Mundial e a Organização para o Desenvolvimento Industrial das Nações Unidas (Rasiah, 2003). As tarifas de importação sobre máquinas, equipamentos e insumos de produção para exportação nestas zonas eram reduzidas, bem como as tarifas de exportação - mais além, proviam-se subsídios para a produção industrial de exportação. Rasiah (2003) resume bem outros incentivos da política industrial, além das ZEEs, de políticas industriais e tributárias - bem como os critérios de elegibilidade e benefícios - nos SEANICs. Alguns deles foram créditos sobre a tarifa (drawback) de importação de máquinas para a produção em geral e de matérias-primas para a produção do setor exportador, isenções de taxas para exportações, isenções fiscais para investimentos, créditos de exportação ${ }^{25}$.

Resumidamente, as ZEEs dos SEANICs apresentaram as seguintes vantagens para as suas empresas: a) importações sem tarifas e sem quotas de matérias-primas, bens intermediários e equipamentos necessários para a produção, b) leis trabalhistas liberais e restrições ao sindicalismo para viabilizar uma estrutura de salários baixos, c) isenções tributárias "generosas" e de longo-prazo, d) melhor infraestrutura e serviços em relação ao restante do país, e) flexibilização de regulações industriais como repatriação de lucros, propriedades estrangeiras de firmas e emprego de funcionários estrangeiros (Furby, 2005). Em contrapartida, a obrigatoriedade de exportar a totalidade ou fatia relevante da produção, além de também atender a critérios de emprego, investimento e entrada de divisas. A operação das ZEEs traduziu-se na coexistência de um regime liberal enquanto a regulação geral para as atividades industriais para o mercado doméstico daqueles países continuaram protecionistas (em especial, durante a década de oitenta). Inicialmente, os setores mais favorecidos foram têxtil, automóveis e peças, e posteriormente eletroeletrônicos/ telecomunicações - dominantes a partir dos anos noventa. As zonas da Malásia e, mais tardiamente, da Tailândia, caracterizavam-se por melhor arcabouço institucional do que as indonésias, tendo alcançado resultados mais efetivos em termos de atração de investimentos e exportações. Do final dos anos oitenta em diante, impuseram uma regulação mais atenta à necessidade de investimentos em tecnologia, treinamento e P\&D (Jomo, 1999).

Assim, diante dos maiores desafios da industrialização orientada para exportações tem sido - a saber, a sofisticação da indústria de transformação e a superação da heterogeneidade estrutural -, é fundamental estipular bem os termos de

(25) Cabe destacar que as tarifas de exportação e sobre o comércio internacional, representaram entre 6 a $12 \%$ das receitas dos SEANICs entre os anos noventa e 2010 (WDI, 2011).

Economia e Sociedade, Campinas, v. 25, n. 1 (56), p. 51-85, abr. 2016. 
investimento, principalmente sobre aprendizado e inovação. $\mathrm{O}$ grande poder das transnacionais, em alguns casos superior ao dos governos desses países, evidentemente exerceu pressão considerável sobre o poder público ao negociar tarifas, taxas de salários, direitos trabalhistas, benefícios fiscais, provisão de infraestrutura etc. Em especial, esses Estados precisaram também exigir transferência tecnológica, treinamento, pagamento de royalties, etc. Concretamente, as multinacionais dos setores intensivos em mão-de-obra, enquanto montadoras e produtoras de staples industriais, embora tenham contribuído em termos de emprego e elevação da renda naquelas áreas, pouco fizeram em termos tecnológicos e de efeitos de encadeamento. Faltaram instituições ou, quando presentes, o enforcement das mesmas. A Malásia e a Tailândia se mostraram mais atentas a esse problema e buscaram impor regras setoriais mais seletivas e também maior monitoramento sobre os resultados. Nos anos noventa, as indústrias do corredor leste da Malásia se tornaram mais intensivas em mão-de-obra qualificada e em tecnologia, também em face da redução relativa de oferta de trabalho e do crescimento dos custos laborais, internacionalizando a operação que agrega menos valor para outras partes da Ásia, destacando as Filipinas e a Indonésia (atrasada em relação às outras em termos de desenvolvimento institucional) (Rasiah, 2003). Na Tailândia, para alavancar P\&D e sofisticar a produção, o governo promoveu políticas como a isenção de tarifas para novos equipamentos, aumentou gastos públicos no setor através de um novo Fundo Tailandês para Pesquisa, e fundou institutos industriais que atuavam como centros de excelência para a inovação nas firmas tailandesas. Ainda que com falhas (Doner, 2009), essas reformas foram realizadas e BOI assumiu oficialmente a migração de uma postura mais liberal e passiva para ativa e interventora - propulsando investimentos, buscando entrada de capitais e divisas e geração de emprego ${ }^{26}$.

Por fim, resta ponderar que as políticas se preocuparam, sobretudo, com a oferta de tecnologia através das universidades, institutos de treinamento, mecanismos de financiamento específicos, laboratórios públicos de pesquisa e serviços técnicos. A melhoria da oferta de serviços educacionais não somente foi uma estratégia de desenvolvimento, como também uma resposta à demanda das empresas e à elevação dos salários reais, à medida que o processo de diversificação começava a esbarrar em barreiras como falta de mão-de-obra qualificada (Doner, 2009). E a questão de demanda da tecnologia, no nível das firmas, recebeu menor ênfase - especialmente no contexto de privatização (Felker, 2003). Sem embargo, a indústria de transformação de maior valor adicionado era de controle das multinacionais, e portanto o progresso tecnológico se resumia aos esquemas intraempresariais, que, geralmente, se originavam fora dos SEANICs. Incentivar

(26) Neste sentido, o BOI criou uma divisão especial para o desenvolvimento de efeitos de encadeamento em 1991, um programa para o ofertante nacional em 1994 e um plano mestre para o desenvolvimento de indústrias auxiliares, em parceria com a agência de cooperação internacional do Japão (Doner, 2009, p. 121). 
sofisticação e efeitos de transbordamento das atividades das multinacionais aí localizadas, portanto, significava elaborar e por em marcha políticas de investimento direto estrangeiro com condicionalidades afins especialmente via obrigatoriedade de transferência de tecnologia e de implantação de centros de P\&D nos países receptores. Porém, até o início dos anos 2000, pouco se avançou também nesta questão.

\section{Conclusões}

O expressivo crescimento dos SEANICs foi liderado pelo setor industrial, que reconfigurou suas estruturas produtiva e exportadora. A expansão industrial se deu tanto através do desenvolvimento dos setores de exportação de recursos naturais, quanto por substituição de importações e também orientada para exportações.

O desenvolvimento industrial por substituição de importações foi deflagrado, em parte, a partir da especialização primária inicial. Seus efeitos de encadeamento levaram ao desenvolvimento de etapas produtivas relacionadas ao processamento dos mesmos e a ganhos de produtividade, e possivelmente aumentos de salários, que ampliaram o mercado doméstico. Até a atualidade os processados de recursos naturais possuem efeitos de encadeamento significativos nas economias dos SEANICs. Esta dinâmica positiva foi em boa medida engendrada e facilitada por políticas públicas de incentivo, protegendo o mercado de importados, com vantagens e financiamento e crédito, concedendo benefícios tributários, relacionando-os às políticas de compras públicas e através de regulamentação estimulante (como no caso de madeira, óleo de palmeira e petróleo).

Já a industrialização orientada para exportações não adveio de encadeamentos, ao contrário fora quase que integralmente implantada nesses países, sem conexão anterior com outras indústrias. Os motivos para essa formação foram internos - política industrial, regime macroeconômico (especialmente cambial) e vantagens de custo -, e externos - basicamente, a nova forma de dinâmica regional comercial e produtiva liderada pelas empresas americanas e japonesas. Conforme visto, os Estados dos SEANICs, centralizados e autoritários, através do planejamento estatal (com a Nova Ordem na Indonésia, a Nova Política Econômica na Malásia, e os planos de desenvolvimento quinquenais tailandeses) e suas agências de fomento, bancos de desenvolvimentos, empresas públicas - principalmente no setor de infraestrutura, e políticas industriais diversas - destacando a constituição de zonas especiais de exportações e de atração de IDE -, desempenharam papel ativo para a diversificação da economia.

Entretanto essa diversificação ainda está longe de proporcionar a superação da heterogeneidade estrutural existente, de modo que o emprego nos setores primários na Indonésia e Tailândia persiste alto relativamente aos países 
desenvolvidos. A pouca sofisticação das exportações industriais, (em maior grau na Indonésia e em menor na Tailândia) não possibilitaram aprofundamento tecnológico endógeno, o que poderia contribuir também para a modernização agrícola. Faltaram, portanto, efeitos de encadeamento entre os dois setores, em boa medida porque faltaram instituições (ou a efetiva atuação das mesmas) que agissem nesse sentido.

\section{Referências bibliográficas}

AMSDEN, Alice. The rise of "the rest": challenges to the West from lateindustrializing economies. New York: Oxford University Press, 2001.

ATHUKORALA, Prema-chandra; DEVADASON, Evelyn. The impact of foreign labour on host country wages: the experience of a Southern Host, Malaysia. Australian National University, Arndt-Corden Department of Economics, 2011. (Departmental Working Papers, 2011-03).

BARHAM, Bradford; COOMES, Oliver. Sunk costs, resource extractive industries, and development outcomes. In CICANTELL, Paul S.; SMITH, David A.; SEIDMAN, G. Nature, raw materials, and political economy. London: Elsevier, 2005.

BM. The East Asian miracle: economic growth and public policy. Banco Mundial. London: Oxford University Press, 1993.

BUNKER, Stephen. Staples, links, and poles in the construction of regional development theories. Sociological Forum, v. 4, n. 4, 589-610, 1989.

; CICANTELL, Paul. Matter, space, time, and technology: how local process drives global systems". In: CICANTELL, P.; SMITH, D.; SEIDMAN, G. Nature, raw materials, and political economy. London: Elsevier, 2005.

CHANG, Ha-Joon. Understanding the relationship between institutions and economic development - some key theoretical issues. In: CHANG, Ha-Joon (Org). Institutional change and economic development. New York: United Nations Press, 2006.

CIA - Central Intelligence Agency. The world factbook: Indonesia, Malaysia, Thailand. 2012. Disponível em: https://www.cia.gov/library/publications/theworld-factbook/.

CICANTELL, Paul; SMITH, David. Nature, raw materials, and political economy: an introduction. In: CICANTELL, P.; SMITH, D.; SEIDMAN, G. Nature, raw materials, and political economy. London: Elsevier, 2005.

DEPARTMENT OF STATISTICS. Governo da Malásia. Matriz Insumo-Produto 2005, 33 atividades. Disponível em: http://www.statistics.gov.my/portal/index. php?lang=en. 
DEQUECH, David. Instituições e a relação entre economia e sociologia. Revista Estudos Econômicos, v. 41, n. 3, p. 599-619, Jul./Set. 2011.

DYMSKI, Gary. On the possible replacement of the efficient-market hypothesis: toward a new economics. In: THE NEW economics as 'mainstream' economics. Cambridge Trust for New Thinking in Economics, Jan. 2010.

DONER, Richard. The politics of uneven development: Thailand's economic growth in comparative perspective. Cambridge: Cambridge University Press, 2009.

FELKER, Greg. Technology policies and innovation systems in Southeast Asia. In: Jomo, K. S. (Ed.). Southeast Asian paper tigers? From miracle to debacle and beyond. London: Routledge Curzon, 2003.

FINDLAY, Ronald; LUNDHAL, Mats. Resource-led growth - A long-term perspective: the relevance of the 1870-1914 experience for today's developing economies. UNU WIDER, 2003. (Working papers, 162).

FOLD, Niels; WHITFIELD, Lindsay. Developing a palm oil sector: the experiences of Malaysia and Ghana compared. 2012. 43p. (DIIS Working Paper, 08).

FURBY, Mats. Evaluating the Malaysian export processing zones with special focus on the electronic industry. Tese (Mestrado)-Lund University, Department of Economics, 2005.

FURTADO, Celso (1976). A economia latino-americana - formação histórica e problemas contemporâneos. São Paulo: Companhia das Letras, 2007.

El desarrollo reciente de la economia venezolana. Borrador Preliminar, Caracas, 1957. Mimeografado.

(1974). Os ares do mundo. In: IGLESI, Francisco (Ed.). Celso Furtado, obra autobiográfica. Rio de Janeiro: Paz e Terra, 1992. Tomo III.

GGDC - Groningen Growth and Development Centre. Dados de emprego e valor adicionado. Disponível em: http://www.ggdc.net/databases/index.htm.

HADIZ, Vedi; ROBINSON, Richard. Reorganising power in Indonesia, the politics of oligarchy in an age of markets. London: Routledge, 2004.

HAZELL, Peter B.; RÖELL, Ailsa. Rural growth linkages: household expenditure patterns in Malaysia and Nigeria. International Food Policy Institute, 1983. (Research Report, 41).

HIRSCHMAN, Albert. The strategy of economic development. New Haven: Yale University Press, 1958

HUTCHCROFT, Paul. Booty capitalism: the politics of banking in the Philippines. New York: Cornell University Press, 1998. 
INNIS, Harold. Problems of staple production in Canada. Toronto: The Ryerson Press. 1933.

JOMO, Kwame Sundaran. Financial liberalization, crises, and Malaysian policy responses. World Development, v. 26, n. 8, p. 1563-1574, 1999.

LANDES, David. The wealth and poverty of nations. New York: WW Norton \& Company, 1998.

LEWIS, W. Arthur (1954). O desenvolvimento econômico com oferta ilimitada de mão-de-obra. In: AGARWALA, A.; SINGH, S. (Org.). A economia do subdesenvolvimento. São Paulo: Forense, 1969.

MACEDO E SILVA, Antonio Carlos. Estrutura produtiva e especialização comercial: observações sobre a Ásia em desenvolvimento e a América Latina. Cadernos do Desenvolvimento, v. 3, n. 82 (5), dez. 2008.

MEDEIROS, Carlos. Natural resources nationalism and development strategies. In: ESHET 2012 Conference, St. Petersburg, 17-19 maio, 2012.

Celso Furtado na Venezuela. In: FURTADO, Celso. Ensaios sobre a Venezuela: subdesenvolvimento com abundância de divisas. Rio de Janeiro: Contraponto, Centro Internacional Celso Furtado, 2008.

NSOT - National Statistical Office of Thailand. Matriz Insumo-produto 1995 e 2005. Disponível em: http://web.nso.go.th/.

NORTH, Douglas. Institutions, institutional change and economic performance. Cambridge: Cambridge University Press, 1990.

OCAMPO, José Antonio. Structural dynamics and economic growth in developing countries. In: FITZGERALD (Ed.). Social institutions and economic development. Holanda: Kluwer Academic, 2007.

PREBISCH, Raul (1949). O desenvolvimento econômico latino-americano e alguns de seus principais problemas. In: BIELSCHOWSKY, R. (Ed.). Cinqüenta anos de pensamento da Cepal. Rio de Janeiro: Record, 2000. v. 1.

RASIAH, Rajah. The export manufacturing experience of Indonesia, Malaysia and Thailand. In: JOMO, K. S. (Ed.). Southeast Asia's Paper Tigers, London: Routledge, 2003.

REIS, Cristina F. B. The role of Japan in the economic development of South East Asian newly industrialized countries. In: CONGRESS OF THE JAPANESE SOCIETY OF POLITICAL ECONOMY, 61. Senshu University, Kanagawa, Japão, 2013. Forth-coming.

ROCHA, Carlos F. Natural resources growth and externalities from natural resource exports. Rio de Janeiro: IE-UFRJ, 2010. (Textos para Discussão, 2903). 
RODRIGUEZ, Octavio (2009) O estruturalismo latino-americano. Rio de Janeiro: Civilização brasileira.

ROOSA, John (2006). Pretext for Mass Murder: The September 30th Movement \& Suharto's Coup D'État in Indonesia. Madison: University of Wisconsin Press.

SENGHAAS, Dieter (1985) The European experience - A historical critique of development theory. New Hampshire: Berg Publishers.

UNIVERSITY OF CAMBRIDGE (1992) The Cambridge History of Southeast Asia. Vol. 1 e 2. TARLING, Nicholas (ed.) Cambridge: Cambridge University Press.

WDI (2011). Banco Mundial. World Development Indicators.

http://data.worldbank.org/data-catalog/world-development-indicators

WIOD. World Input-output database: Indonesia.

http://www.wiod.org/database/nat_suts.htm

OMC (2012) Organização Mundial do Comércio - International trade and tariff data. Historical Series, Trade profiles.

http://www.wto.org/english/res_e/statis_e/Statis_e.htm

WRIGHT, Gavin; CZELUSTA, Jesse (2003) "Mineral resources and economic development". In: Conference on sector reform in Latin America, Stanford University, Nov. 13-15, 2003. 